\title{
Corrosion and corrosion management investigations in seawater reverse osmosis desalination plants
}

\author{
Nicolas Larché ${ }^{a,{ }^{*}}$, Philippe Dézerville ${ }^{b}$ and Denise Le Flour ${ }^{c}$ \\ a Institut de la Corrosion, Marine Corrosion, 220 rue Pierre Rivoalon, Brest, 29200, France \\ b Véolia, Direction Technique et Opérations, 1 rue Battista Pirelli - Bâtiment B - Bureau 221 F-94410, Saint- \\ Maurice, France \\ c Ifremer, Développements Technologiques Matériaux et Structures, Brest, 29280, France \\ *: Corresponding author : Nicolas Larché, Tel. +33 (0) 298051552
}

\begin{abstract}
:
To comply with the demanding operational conditions of seawater reverse osmosis (SWRO) process, both in terms of corrosion resistance and mechanical properties, the conventional metallic material selection was often stainless steel for seawater and brines handling units (e.g. pumps, valves and piping). However, many cases of corrosion failures of stainless steel in SWRO desalination units have been reported often attributed to un-adapted stainless steel grade selection and/or to the particular aggressive conditions in "warm" regions where many recent desalination plants are built (high ambient temperature, severe biofouling, etc.). The operational corrosion risk will actually highly depend on the material composition, on the metallurgy (i.e. cast or wrought), on the service conditions and on the geometrical configuration of the concerned units in contact with seawater. Considering all these parameters, a proper material selection should avoid corrosion issue. For existing corrosion, cathodic protection (CP) may be an efficient solution to stop or to control the propagation of the degradation. However, the CP for materials used in SWRO desalination plants and in its specific operational conditions (i.e. high pressure, velocity and confinements) is not well documented; as a result, an adapted CP design is not always possible from existing data. The present paper reviews some corrosion cases of stainless steel and copper-based alloys in SWRO desalination plants. Solutions to manage existing corrosion of metallic materials in SWRO plants are discussed and focus is done on $\mathrm{CP}$ of stainless steel elements. Some results of an ongoing investigation about the CP for the specific operational conditions of SWRO desalination plant are presented and discussed.
\end{abstract}

Keywords: Corrosion ; Seawater reverse osmosis ; Metallic materials ; Stainless steels ; Cathodic protection 


\section{Introduction}

Due to high chloride content, high pressures and dissolved oxygen content at saturation, material selection for seawater reverse osmosis (SWRO) units requires special attention to avoid mechanical and/or corrosion failures. In these demanding applications, the conventional material selection has been typically stainless steels with "sufficient" pitting resistant equivalent number. However, many cases of corrosion failures of stainless steel in SWRO desalination units have been reported. In most cases, the cause of the failure was attributed to the use of not enough alloyed grades for seawater handling applications such as UNS S31603 (316L), S 31703 (317L) and N08904 (904L), which are highly susceptible to pitting and crevice corrosion in seawater at ambient temperatures [1]. Such alloys should never be used in seawater at ambient temperature. More alloyed stainless steels materials with Pitting Resistance Equivalent Number (i. e. PREN $=\% \mathrm{Cr}+3.3 \% \mathrm{Mo}+16 \% \mathrm{~N}$ ) above 40 are also susceptible to pitting and crevice corrosion in seawater and the operational corrosion risk will highly depend on the service conditions (e. g. temperature, chlorination, etc.), the metallurgy of the product (wrought or cast alloys) and on the geometrical configuration of the confined zones in contact with seawater [2-4]. For instance, several cases of crevice corrosion of flanges made of superaustenitic UNS S31254 and superduplex UNS S32750, the PREN of which are above 40, have been reported for seawater applications [5-7]. Hence, the use of stainless steel grades for SWRO application should be performed with special care, especially in places where seawater is above $15^{\circ} \mathrm{C}$ (e. g. Middle-east desalination plants).

Copper-based alloys are also widely used in seawater. They show attractive characteristics such as good resistance to corrosion, high thermal conductivity and good mechanical properties. Furthermore, they are considered as having a high resistance to biofouling which is a key advantage over other metallic materials in natural seawater applications. Typical applications in marine environments include heat exchangers, seawater piping, pumps and valves, propellers, shafts and offshore sheathing. Among these alloys, the most frequently used in the marine environment are copper nickel alloys (90/10 and 70/30) and Nickel Aluminium Bronze (NAB). Despite their extensive use, some corrosion failures of copper alloy components have been experienced [8]. Corrosion failures of copper-based alloys are generally caused by the combination of environmental (seawater pollution, temperature), operating factors (flow velocity or chlorination) or not suitable composition or metallurgy.

When the metallic material is not adapted (e. g. low grade stainless steel in chloride containing media or unadapted copper alloy in polluted seawater) corrosion may initiate and propagate very quickly. Where the operating conditions cannot be changed (e. g. deaeration, corrosion inibitors, etc) there is generally two options:

- Change the material to a corrosion resistant alloy

- Implement a system or a treatment to stop or control the existing corrosion

The first solution may be extremely costly and often not possible. For the second option, one of the most efficient and economical solution to prevent the propagation of the degradation on metallic materials is to apply an adapted cathodic protection. It is well known that "lowcorrosion resistant" metallic materials (e. g. carbon steels) can be used in seawater handling systems under appropriate cathodic protection. Cathodic protection design of offshore structures made of carbon steels is rather well documented in the literrature and in standards [9-11]. The principle of the cathodic protection (CP) is to negatively polarize a metal in order to lower its corrosion potential below its immune domain (i. e. potential for which the corrosion rate is considered negligible). A so-called Pourbaix diagram showing domains of 
stability as a function of $\mathrm{pH}$ and potential helps at understanding the principle of the method. An example of Pourbaix diagram of iron in water is given in Figure 1. For a given $\mathrm{pH}$ and $\mathrm{Fe}$ concentration, it exists a minimum potential at which metallic $\mathrm{Fe}$ is stable, i. e. "immune". From Figure 1, at seawater $\mathrm{pH}$ of 8 , the protective potential is given at about $-530 \mathrm{mV} / \mathrm{SHE}$ (Standard Hydrogen Electrode), corresponding to about $-780 \mathrm{mV} / \mathrm{AgAgCl} / \mathrm{seawater}$ (main measurement electrode used in seawater). To operate in safe conditions when using iron, the standards give minimum potential protection criteria between -800 and $-900 \mathrm{mV}$ $/ \mathrm{AgAgCl} /$ seawater (the lowest potential is recommended where there is a risk of Microbiologically Influenced Corrosion) [9-11].

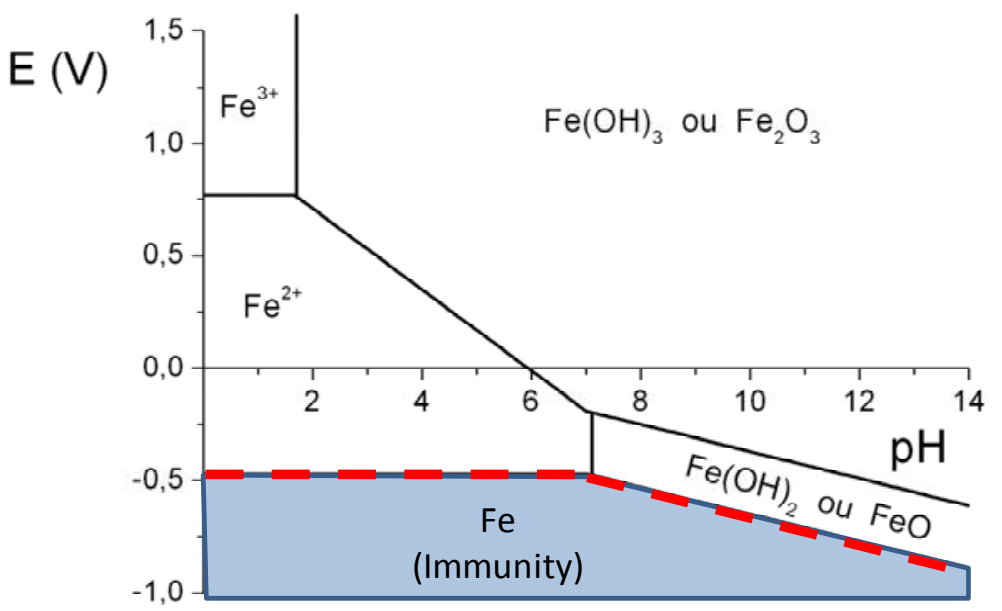

Figure 1: Example of Pourbaix diagram of iron $(\mathrm{Fe})$ in water. Potential is given versus Standard Hydrogen Electrode (SHE)

Cathodic protection is ensured by continuous current injection from the electrolyte to the metal. It can be achieved using galvanic (or sacrificial) anodes, or impressed current from rectifiers (i. e. current generators). In the first case (i. e. cathodic protection with sacrificial anodes) the required current to polarize the structure to be protected is provided by the less noble metal (i. e. the sacrificial anode) according to oxido-reduction reactions. In the second method (i. e. cathodic protection with impressed current), the required current to polarize the structure to be protected is provided by a current generator, called rectifier. For further information, the basic generalities about the principle of cathodic protection is largely detailed in the literature $[11,12]$.

However, in the particular service conditions of seawater reverse osmosis desalisation plants (e. g. high pressures, high velocities, confinements, treated seawater, stainless steels structures with large metallic area, etc.), the actual efficiency of cathodic protection may be strongly affected. From the literature and the existing standards, there is a lack of data for cathodic protection adapted to the materials, the designs and the operating conditions used in desalination units. Thus it appeared useful to collect and analyze data from both laborotory and field tests in order to define an adapted cathodic protection design for specific units of SWRO process. Hence, a study entitled "Cathodic Protection Design for Specific Applications of Seawater Reverse Osmosis Desalination Plants" has been initiated. The development of specific monitoring (e. g. continuous monitoring in field pressure pumps, laboratory monitored devices) was proposed to get both field and laboratory data. Finally, these specific cathodic protection data are used in a cathodic protection modelling software 
called PROCOR ${ }^{\mathrm{TM}}$. The modeling from $\mathrm{PROCOR}^{\mathrm{TM}}$ is validated from field measurements and can be used to design the $\mathrm{CP}$ of any other specific applications.

In the present paper, a brief review of corrosion behavior and corrosion cases from seawater desalination units operating at ambient temperature are presented and discussed, for both stainless steels and copper-based alloys. The issues related to the efficiency of cathodic protection in desalination units are reviewed and some results from the "cathodic protection" study are presented together with some modeling work.

\section{Corrosion of stainless steels in SWRO units: review and corrosion cases}

Stainless steels have been extensively used for a wide range of applications in seawater. In seawater desalination reverse osmosis industry, it has been the conventional materials used for high pressure inlet piping to the RO membrane module, brine rejection pipe, product water outlet pipe and high pressure pumps.

It exist a huge range of stainless steel grades and a careful selection is required to avoid corrosion issues which are highly dependent on the service conditions during operation and on the geometry of the units. The simultaneous addition of $\mathrm{Cr}$, Mo and $\mathrm{N}$ has obvious beneficial effects on the pitting and crevice corrosion resistance of stainless steel in chloride-containing environments [13], as a result they are often characterized by a formula called PREN (Pitting Resistant Equivalent number) given by PREN $=\% \mathrm{Cr}+3.3 \% \mathrm{Mo}+16 \% \mathrm{~N}[13,14]$. It results in quasi-linear relationships when plotted versus the critical pitting temperature (CPT) and/or the crevice corrosion temperature (CCT) in oxidant media. However, the PREN must be used with special care since this number does not consider other very important parameters such as the metallurgical quality, the nickel content or the surface state. Also the standard ASTM G48 A and B [15] used to determine the CPT and CCT of stainless steels cannot be used as an absolute criteria for material selection for seawater applications since the conditions of these standard tests are completely different to that of service conditions.

\section{Stainless steels with PREN below 35}

As a general rule, these stainless steel grades are not adapted to resist localized corrosion in seawater handling applications at ambient temperature. In most desalination plants where UNS S31603 (316L) or UNS S31703 (317L) stainless steel were used, dramatic pitting and crevice corrosion occurred [1]. Pitting and crevice corrosion were also several times reported for the more alloyed UNS N08904 (904L) stainless steel grade. The crevice corrosion propagation of some "low alloy" stainless steels was evaluated in seawater at different temperatures [2]. The crevice assemblies used for the investigation were based on the Crevcorr-type assembly involving plastic crevice formers tightened to the welded plate specimens with a torque of $3 \mathrm{Nm}$ on M5 titanium bolts [16]. This assembly led to a "not severe" crevice geometry with calculated pressure under gasket of $3 \mathrm{~N} / \mathrm{mm}^{2}$. Photograph of the assembly is shown in Figure 2 and some general results are given in Figure 3. It is shown that all the tested alloys with PREN equal or below 26 exhibited severe crevice corrosion in aerated seawater at $20^{\circ} \mathrm{C}$. The duplex stainless steel UNS S32205 with a PREN at 37 failed at $30^{\circ} \mathrm{C}$. However, since the initiation and propagation of crevice corrosion strongly depend on the severity of the crevice, these data are only comparative and crevice corrosion may be initiated on UNS S32205 at lower temperature [17]. 


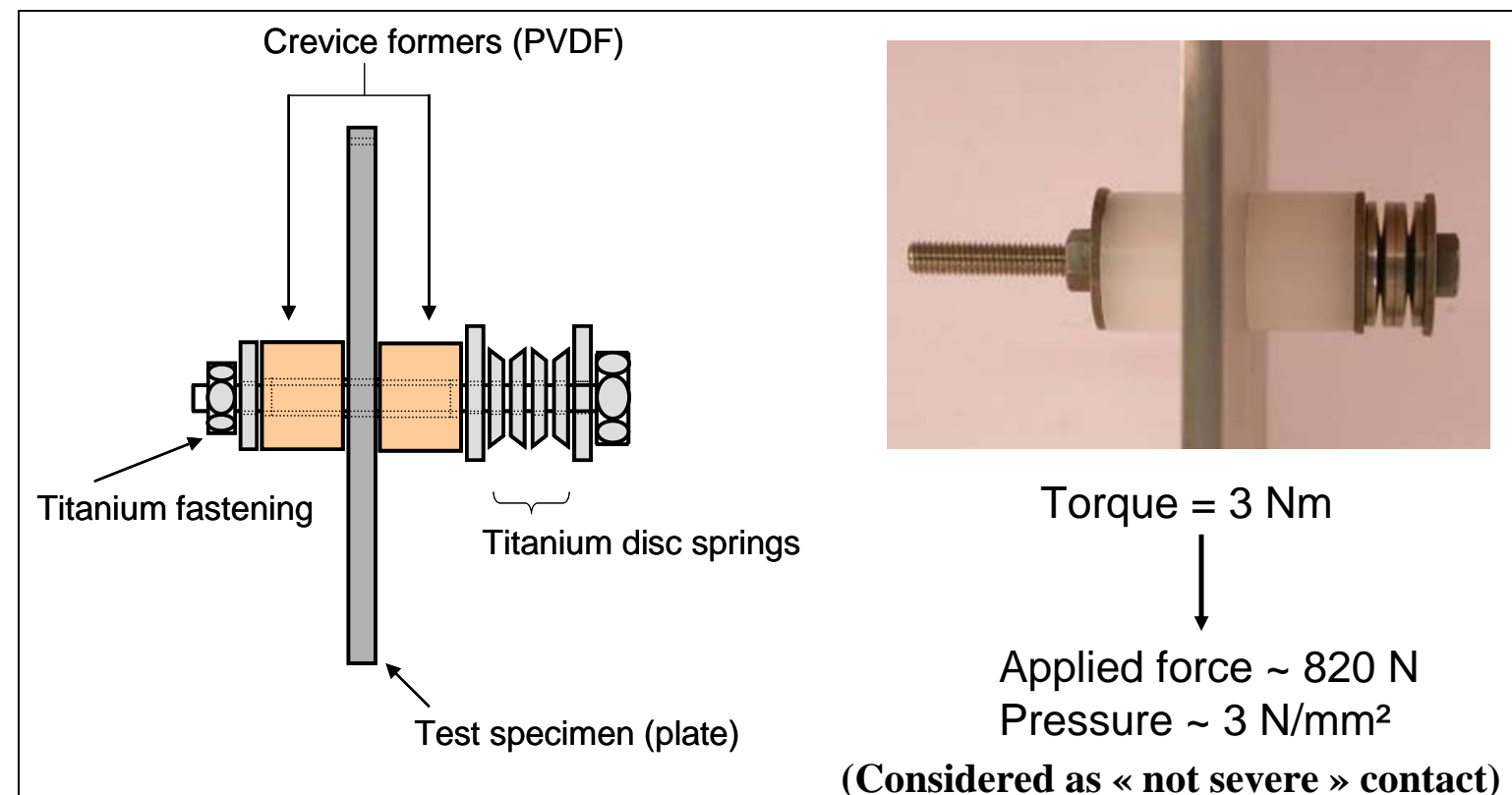

Figure 2 : Crevcorr-type assembly for crevice corrosion testing

\begin{tabular}{|c|c|c|c|c|}
\hline & $\begin{array}{l}\text { UNS. } \\
\text { PREN }\end{array}$ & $\begin{array}{c}\text { S30403 } \\
\mathbf{2 0}\end{array}$ & $\begin{array}{c}\text { S31603 } \\
\mathbf{2 6}\end{array}$ & $\begin{array}{c}\text { S32205 } \\
\mathbf{3 7}\end{array}$ \\
\hline $\begin{array}{l}\frac{0}{\frac{1}{L}} \\
\frac{0}{\frac{0}{c}}\end{array}$ & $\begin{array}{c}30^{\circ} \mathrm{C} \\
\text { Aerated - Renewed } \\
\text { Chlorine } 0.5 \mathrm{ppm}\end{array}$ & & & \\
\hline \multirow{3}{*}{ 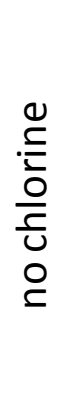 } & $\begin{array}{c}30^{\circ} \mathrm{C} \\
\text { Aerated - Renewed }\end{array}$ & & & \\
\hline & $\begin{array}{c}20^{\circ} \mathrm{C} \\
\text { Aerated - Stagnant }\end{array}$ & & & \\
\hline & $\begin{array}{c}5^{\circ} \mathrm{C} \\
\text { Aerated - Stagnant }\end{array}$ & & & \\
\hline
\end{tabular}

Figure 3 : Results from crevice corrosion tesing using Crevcorr-type assembly on welded stainless steel with PREN ranging from 20 to 37. Results only valid with the tested crevice geometry. Crevice geometry should be considered as "not severe" [2, 18].

\section{Stainless steels with PREN between 35 and 40}

One of the most selected stainless steel grade for seawater applications such as desalination pumps was the duplex 2205 (UNS S31803 or UNS S32205) with PREN 35-38. This is due to 
a good compromise between mechanical properties, corrosion resistance and cost. However, it is now widely admitted that the critical crevice corrosion temperature of UNS S31803 or S32205 in seawater is clearly below $20^{\circ} \mathrm{C}$, depending on the severity of the crevice geometry [7]. From both field and laboratory data, in seawater at about $30^{\circ} \mathrm{C}$, the risk of pitting and crevice corrosion with dramatic propagation is very high for this stainless steel grade $[2,4,7$, 18-20]. The use of such stainless steel grades is thus not recommended in any seawater handling systems of SWRO desalination plants, without additional protection (e. g. carefully designed cathodic protection).

The corrosion of a seawater high pressure (HP) booster pump was investigated in a SWRO desalination plant in Mediterranean sea coast [21]. The typical composition of the booster pump is given in Table 1 and photographs of the corroded pump are given in Figure 4 and in Figure 5. Crevice corrosion at the gasket location and severe pitting corrosion on the open surface were observed. The seawater circulating inside the pump had a temperature between $20^{\circ} \mathrm{C}$ and $35^{\circ} \mathrm{C}$ with some stagnation periods. Regarding the rather high ambient temperatures and referring to the comments above, crevice and pitting corrosion was clearly expected for such cast grade in the actual service conditions. The extremely severe extent of pitting corrosion on open surface was however attributed to the not adapted stagnation periods.

Table 1 : Typical composition of DIN 1.4468

\begin{tabular}{|c|c|c|c|c|c|c|c|c|}
\hline $\mid \overline{C r}$ & $\mid \overline{N i}$ & $\overline{\text { Mo }}$ & $\mathbf{N}$ & C & $\mathbf{S}$ & $\mathbf{P}$ & $\mathbf{M n}$ & $\overline{\mathbf{S i}}$ \\
\hline $\begin{array}{l}24,5 \\
26,5\end{array}$ & $\begin{array}{l}5,5 \\
7,0\end{array}$ & $\begin{array}{l}2,5 \\
3,5\end{array}$ & $\begin{array}{l}0,12 \\
0,25\end{array}$ & $<0,05$ & $<0,025$ & $<0,03$ & $<1,00$ & $<1,00$ \\
\hline
\end{tabular}



Figure 4 : Crevice and pitting corrosion of the casing of a HP booster pump (cast duplex stainless steel UNS J93550, DIN 1.4468) 


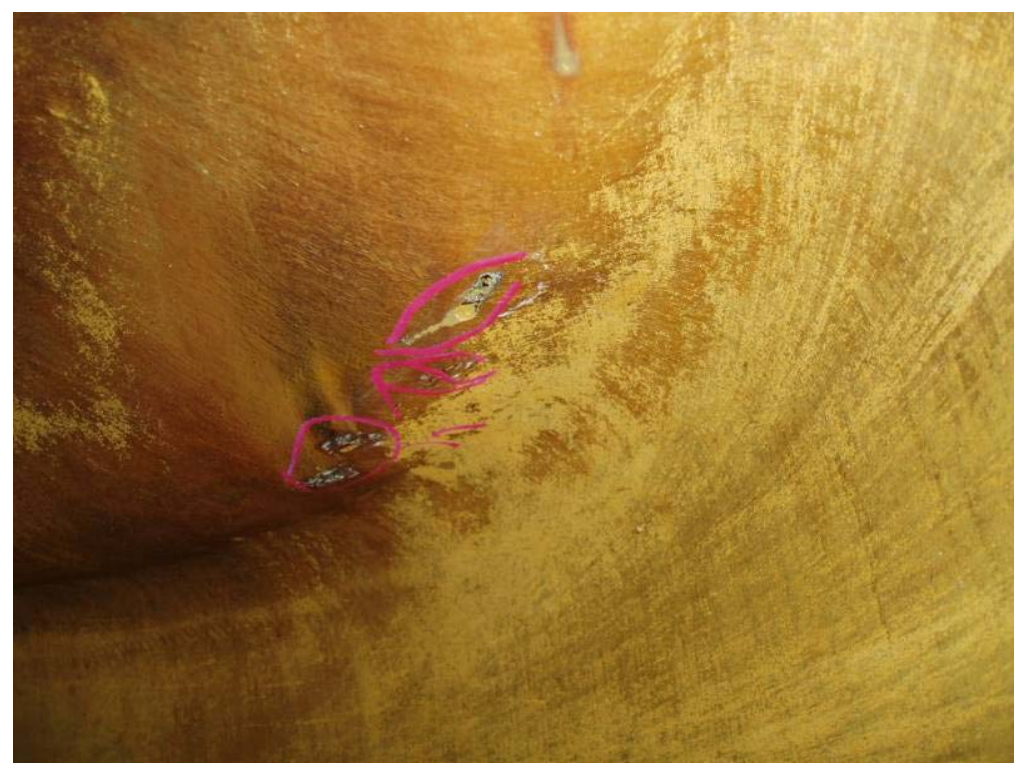

Figure 5 : Pitting corrosion of the casing of a HP booster pump (cast duplex stainless steel UNS J93550, DIN 1.4468)

\section{Stainless steels with PREN above 40 (superduplex and superaustenitic stainless steels)}

Despite the lack of precision of the PREN discussed above, any stainless steel grade with pitting resistant equivalent number (PREN) above 40 is called "superduplex" or "superaustenitic" stainless steel. Some decades ago, most corrosion problems in seawater were expected to disappear with the use of these high alloy stainless steel grades [22]. However, several cases of pitting and crevice corrosion appeared in field service conditions $[5-7,22,23]$ which led to the need to better understand the parameters which influence crevice corrosion of stainless steels. Today, a significant experience is available together with laboratory results, enabling a safer use of these high alloy stainless steels for seawater applications. In some recent recommendations, the upper temperature limit for a safe use of stainless steels with PREN of 40 decreased below $20^{\circ} \mathrm{C}$ in some seawater applications where thigh crevices are involved [24]. However, in addition to the importance of the composition, product form and surface state/treatment, the limits of utilization of "super" stainless steels in seawater are highly dependent on the crevice geometry and/or the service conditions of each specific application [2, 3]. For instance, the importance of crevice geometry on localized corrosion susceptibility was clearly shown on the superduplex UNS S32750 (superduplex type 2507) from several studies in our research institute [3]. CREVCORR-type assemblies were used at different gasket pressure levels, and it was clearly shown to exhibit very different results [3] (i. e. the higher the gasket pressure, the higher the risk of crevice corrosion initiation). This underlines the complex nature of localized corrosion initiation and the need to be able to characterize as precisely as possible the involved service conditions and crevice geometries. This is illustrated in Figure 6 which summarizes some results in both natural and chlorinated seawater for the superduplex UNS S32750 and the superaustenitic UNS S31266 [3]. It is shown that in natural seawater, UNS S32750 hot rolled plates with Ra $3 \mu \mathrm{m}$ were crevice corrosion resistant from $20^{\circ} \mathrm{C}$ to $50^{\circ} \mathrm{C}$ with a gasket (i. e. CREVCORRtype) pressure of $3 \mathrm{~N} / \mathrm{mm}^{2}$, while it showed crevice corrosion at $30^{\circ} \mathrm{C}$ when the gasket pressure was increased to $20 \mathrm{~N} / \mathrm{mm}^{2}$. In the seawater of Brest, $30^{\circ} \mathrm{C}$ is the optimal temperature for biofouling activity (no biofilm ennoblement is observed above $40^{\circ} \mathrm{C}$ ), which may explain why no crevice corrosion occurred at $50^{\circ} \mathrm{C}$. Also no corrosion occurred at $20^{\circ} \mathrm{C}$ despite the biofilm ennoblement, which underlines the importance of temperature in the 
initiation of crevice corrosion. Under similar conditions of exposure, it is interesting to notice that the more alloyed stainless steel UNS S31266 resisted crevice corrosion for all the tested configurations. In chlorinated seawater, the critical crevice corrosion temperatures for superduplex stainless steel are clearly decreased (see Figure 6-b).



(a) Natural seawater

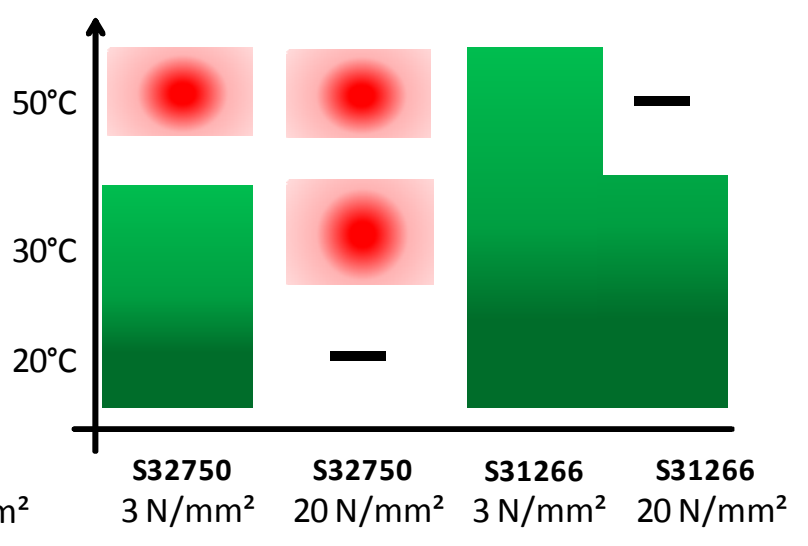

(b) 0.5 ppm-chlorinated seawater

Figure 6: Effect of temperature and pressure of CREVCORR-type crevice formers on UNS S32750 and $S 31266$ hot rolled plates on the crevice corrosion susceptibility (plate roughness Ra $3 \mu \mathrm{m}$ ), in (a) natural seawater, (b) 0.5 ppm-chlorinated seawater [3]

Due to elemental segregation and other factors (e. g. microstructure), cast grades have lower corrosion threshold values than the wrought grades $[19,25]$. For instance, the ASTM A890 Gr5A (=UNS J993404) is clearly expected to be more susceptible to crevice and pitting corrosion than its wrought equivalent UNS S32750. In addition, laboratory experiments clearly showed that once initiated, crevice corrosion propagated more dramatically in cast superduplex stainless steels compared to wrought superduplex stainless steels, in seawater from $15^{\circ} \mathrm{C}$ to $40^{\circ} \mathrm{C}$ [26]. In the same study it was shown that the tendency to repassivation was also much lower for cast versions. This is the reason why some pump manufacturers recently preferred the mechanized welding (of wrought materials) to replace the casting versions. Yakuwa et al evaluated the crevice corrosion resistance of rolled (wrought) and cast duplex and super duplex stainless steels used for seawater pumps in different seawaters [4]. Investigations were performed in Arabian Gulf with raw seawater and chlorinated seawater, and the authors clearly showed that cast materials, even with PREN above 40, exhibited much lower corrosion properties than their rolled (wrought) equivalent.

The corrosion of a seawater pump made of cast superduplex stainless steel was investigated in a SWRO desalination plant in Mediterranean sea coast [21]. The typical composition of the pump is given in Table 2 and photographs of the corroded pump are given in Figure 7 and Figure 8. Crevice corrosion at gasket location and severe pitting corrosion on open surfaces were noticed. The seawater circulating inside the pump had a temperature between 20 and $35^{\circ} \mathrm{C}$ with some stagnation periods. The seawater circulating inside the pump was analysed and did not revealed abnormal corrosiveness compared to typical Mediterranean seawater. Regarding the rather high ambient temperatures, crevice and pitting corrosion was expected for such cast grade. However, the extremely severe extent of pitting corrosion was attributed 
to un-adapted stagnation periods. The proposed solutions to stop or at least decrease corrosion in the existing desalination plant were:

- Change the "stop" procedure (e. g. permanent flow in the pumps or flush with fresh water)

- $\quad$ and install a specific cathodic protection for each pump

If the cathodic protection is not efficient in very confined zones (e. g. external parts of flanges), welding of thin sheet of a corrosion resistant Ni-based material (i. e. UNS N06276, N06022, N06200 or N06059) could be used in the critical parts. In that case, adapted filler materials containing high amounts of $\mathrm{Cr}$ and $\mathrm{Mo}$ and adapted welding procedures must be used [27].

Table 2 : Typical composition of cast superduplex stainless steel ASTM A890 Gr5A (UNS J93404)

\begin{tabular}{|c|c|c|c|c|c|c|c|c|}
\hline $\mathbf{C r}$ & $\mathbf{N i}$ & Mo & $\mathbf{N}$ & C & $\mathbf{S}$ & $\mathbf{P}$ & Mn & $\mathbf{S i}$ \\
\hline $\mid$\begin{tabular}{|l}
24,0 \\
26,0
\end{tabular} & $\begin{array}{l}6,0 \\
8,0\end{array}$ & $\begin{array}{l}4,0 \\
5,0\end{array}$ & $\begin{array}{l}0,1 \\
0,3\end{array}$ & $<0,03$ & $<0,025$ & $<0,03$ & $<1,5$ & $<1,00$ \\
\hline
\end{tabular}

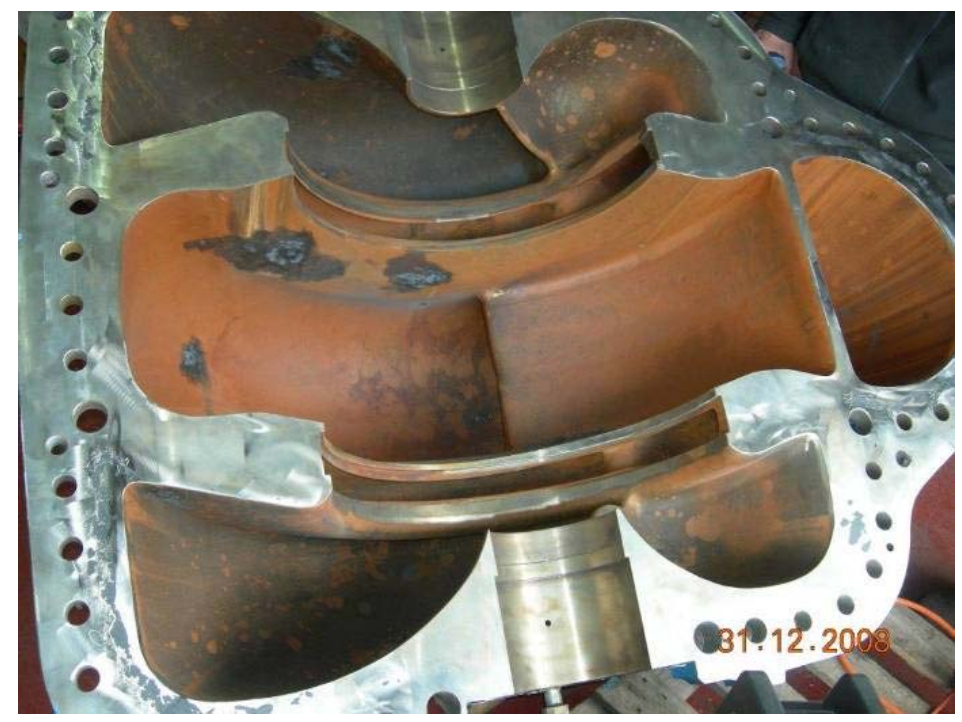

Figure 7 : Overview of the corroded pump made of cast superduplex stainless steel ASTM A890 Gr5A (UNS J93404)
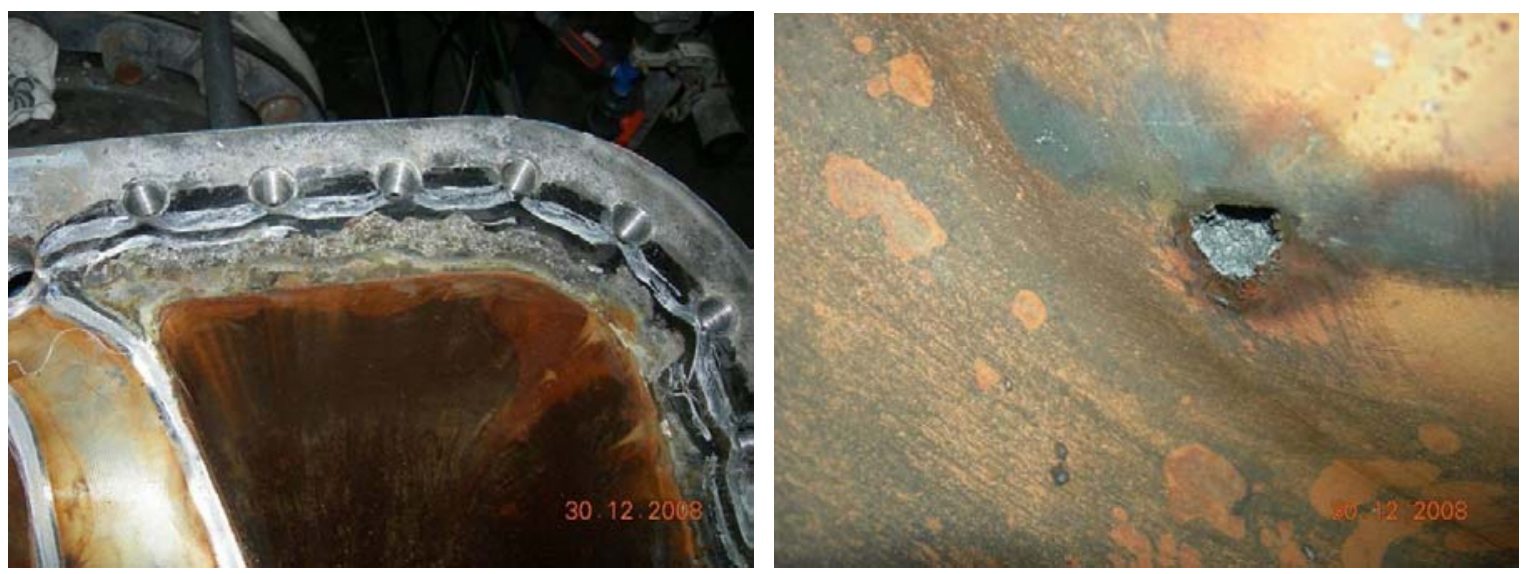

Figure 8: Crevice (a) and pitting (b) corrosion of pump made of cast super duplex stainless steel ASTM A890 Gr5A (UNS J93404) 
Other examples of crevice corrosion of both cast and wrought superduplex stainless steels installed in a SWRO desalination where the ambient temperature was high are given in Figure 9. The importance of using good engineering practice for the welding of high alloy stainless steel is clearly illustrated in Figure 10, where superduplex stainless steel pipes perforated after short operating period at welds that were not performed according to standard practice.
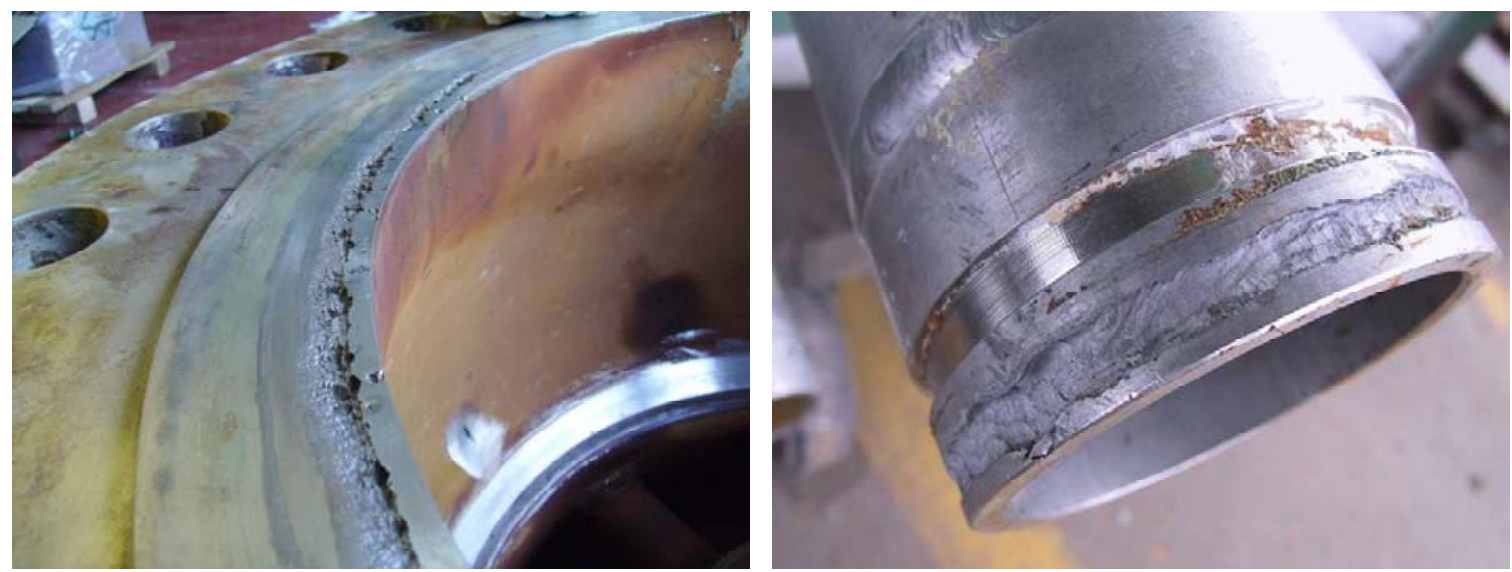

Figure 9: (a) Crevice corrosion of a cast superduplex stainless steel at gasket location, (b) crevice corrosion of a wrought superduplexduplex stainless steel at a "Victaulic-type" connection.
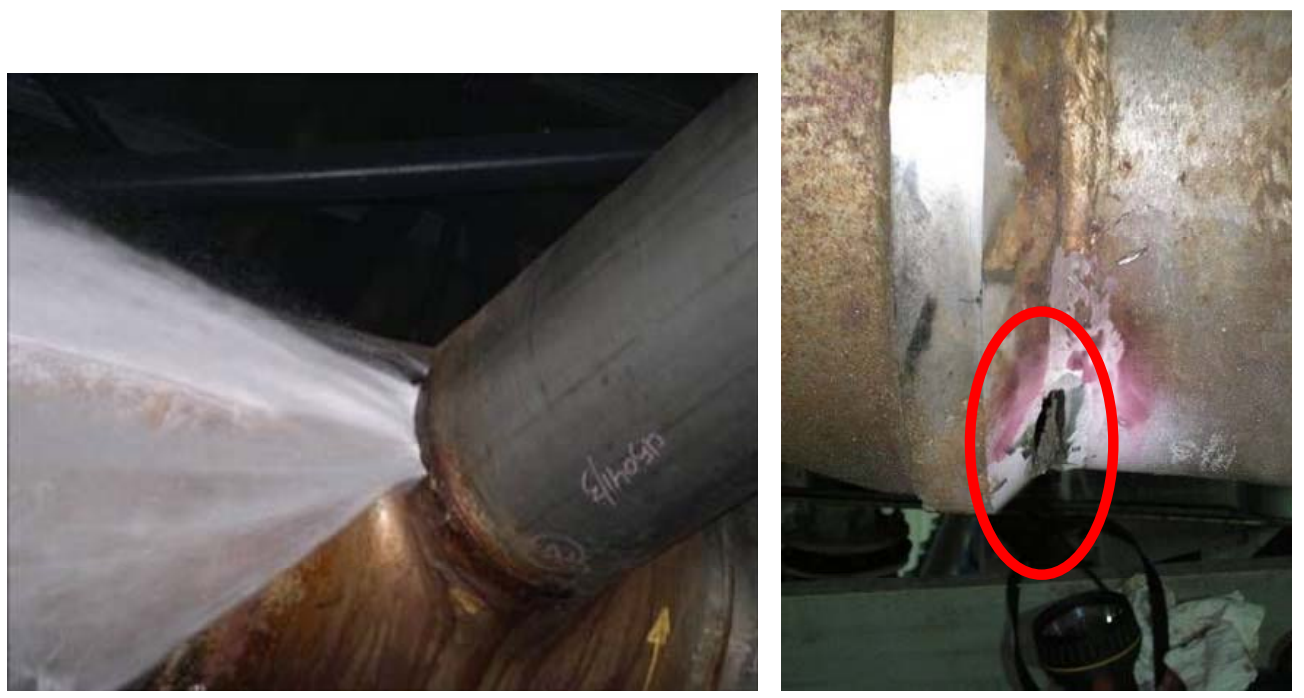

Figure 10 : Perforating pitting corrosion at welds on superduplex stainless steel pipes. In these cases, welding was not performed according good engineering practices.

\section{Corrosion of copper-alloys in desalination unit: review and corrosion case}

Copper alloys such as Admiralty brass, Aluminium brass, CuNi90/10, CuNi70/30 or NickelAluminium Bronze (NAB) are widely used in seawater handling systems. Their typical compositions are given in Table 3. 
Table 3: Typical composition of 5 main copper based alloys used in seawater applications

\begin{tabular}{|c|c|c|c|c|c|c|c|}
\hline Usual designation & $\mathbf{N}^{\circ} \mathbf{U N S}$ & $\mathbf{C u}$ & $\mathbf{N i}$ & $\mathbf{Z n}$ & $\mathbf{F e}$ & $\mathbf{M n}$ & other \\
\hline Admiralty Brass & $\mathbf{C 4 4 3 0 0}$ & bal. & - & $23-30$ & - & - & - \\
\hline Aluminium Brass & $\mathbf{C 6 8 7 0 0}$ & $76-79$. & - & bal. & - & - & $\begin{array}{c}\mathrm{Al}=1.8-2.5 \\
\mathrm{Ar}=0.02-0.06\end{array}$ \\
\hline $\mathbf{C u}-\mathbf{N i} \mathbf{9 0 / 1 0}(\mathbf{1 , 5} \mathbf{~ F e})$ & $\mathbf{C 7 0 6 0 0}$ & bal. & $9-11$ & $<0.5$ & $1-2$ & $0.5-1$ & - \\
\hline $\mathbf{C u}-\mathbf{N i} \mathbf{7 0 / 3 0}(\mathbf{1 , 5} \mathbf{F e})$ & $\mathbf{C 7 1 6 4 0}$ & bal. & $29-33$ & $<0.5$ & $1-2$ & $1.5-2.5$ & - \\
\hline NAB & $\mathbf{C 9 5 5 0 0}$ & bal. & $4-6$ & - & $\begin{array}{c}4- \\
5.5\end{array}$ & $<3$ & $\mathrm{Al}=8.5-10.5$ \\
\hline
\end{tabular}

Copper alloys are known to be naturally resistant to fouling due to the release of copper ions which have biocide properties. This property is particularly interesting in seawater applications to reduce cleaning operations without the use of biocide treatments (e. g. chlorination). However copper alloys may exhibit selective corrosion during the "clean-up" of the installation and the release of copper ions may deteriorate membranes. This is one of the reasons why stainless steels have been generally preferred for the construction of SWRO units. Also, copper alloys are sensitive to operating conditions (pollution, velocity, seawater treatment) and may experience corrosion failures in seawater applications [8].

The deleterious effect of sulphides on corrosion of copper alloys is a well-known phenomenon [28, 29]. Sulphide is a pollutant which may be introduced into seawater as a result of effluent discharge or formed by biological activity and decay by sulfato-reducing bacteria (SRB). In stagnant or confined configurations, some aerobic bacteria can consume dissolved oxygen and, then, anaerobic bacteria like SRB are activated. The hydrogen sulfide generated by these bacteria could lead to dramatic corrosion of most copper alloys in aerated seawater. For deaerated seawater, the sulphide effect is rather low, i.e. the corrosion rate is low, unless this water is mixed with aerated water.

In addition, copper alloys are highly susceptible to bimetallic corrosion when coupled to "corrosion resistant" stainless steels which are widely used in SWRO desalination plants [30, $31]$.

Copper alloys can also be strongly affected by erosion corrosion in systems where the flow rate is high. Standard recommendations to avoid erosion corrosion are given in Table 4 [32]. Seawater stagnation should clearly be avoided and a sufficient flow rate must be ensured to avoid deposit which could lead to differential aeration cells and to localized corrosion under deposits. 
Table 4: Maximum flow rate in copper-based piping systems to avoid erosion corrosion [32]

\begin{tabular}{|c|c|c|c|}
\hline \multirow{3}{*}{ Copper alloy } & \multirow{2}{*}{\multicolumn{3}{|c|}{$\begin{array}{l}\text { Maximum flow rate } \\
{[\mathrm{m} / \mathrm{s}]}\end{array}$}} \\
\hline & & & \\
\hline & $<100$ & $100-250$ & $>250$ \\
\hline Admiralty Brass & 1,5 & 1,5 & 1,5 \\
\hline Aluminium Brass & 1,8 & 2,4 & 3,9 \\
\hline Cu-Ni 90/10 (1,5 Fe) & 2,5 & 3,0 & 3,5 \\
\hline $\mathrm{Cu}-\mathrm{Ni}$ 70/30 $(1,5 \mathrm{Fe})$ & 3,0 & 3,6 & 4,5 \\
\hline
\end{tabular}

However, copper-nickel alloys generally showed excellent corrosion resistance for many seawater applications (chlorinated or not) regarding that flow velocity, geometrical design, and galvanic coupling are controlled. Then the use of copper alloys in existing SWRO desalination plants may be considered, regarding the following recommendations:

- check that the exact composition is conform to the standard requirements (a composition out of the typical range may have strong impact on the corrosion resistance),

- ensure that the flow rate of seawater is in the range defined in Table 4 and avoid zones of turbulence,

- avoid galvanic coupling with any other metallic alloy,

- ensure a "good" formation of the initial oxide layer, with flowing of "clean" seawater or soft water in the first days of use, and check seawater composition (i. e. avoid detrimental pollution),

- avoid any prolonged stop which could lead to stagnant seawater in contact with the copper alloy,

- ensure that copper ion release is compatible with the used membranes.

A corroded drain valve from a seawater treatment plant in the Middle East was inspected. The disc was made of nickel-aluminium bronze and presented numerous corrosion products buildup on the side in contact with the seawater. The corroded valve drain valve was positioned at the bottom of a seawater tank. Regarding the configuration, the water in contact with the valve was supposed to be quiescent but periodical opening of the valve could have been done in order to renew the seawater. The seawater temperature was between $15^{\circ} \mathrm{C}$ and $36^{\circ} \mathrm{C}$. However, as the outside part of the valve was exposed to the sun, peak temperature of $80^{\circ} \mathrm{C}$ was possible.

The disc of the valve was made of a Nickel aluminium bronze, CC 333G grade according to the French standard NF EN 1982(2008). The composition analysis confirmed that the grade corresponded to the nickel-aluminium bronze UNS C95800 (see Table 5). 
Table 5 : Composition of the nominal properties of tested coatings (in wt. \%)

\begin{tabular}{lllllllll}
\hline & $\mathbf{C u}$ & $\mathbf{A l}$ & $\mathbf{N i}$ & $\mathbf{F e}$ & $\mathbf{M n}$ & $\mathbf{S i}$ & $\mathbf{P b}$ & $\mathbf{S n}$ \\
\hline Analysis & 80 & 9.2 & 5.5 & 5.1 & 0.092 & 0.044 & 0.019 & 0.010 \\
\hline Standard & $76-$ & $8.5-$ & $4.0-6.0$ & $4.0-5.5$ & $<3.0$ & $<0.1$ & $<0.03$ & $<0.1$ \\
CC333G & 83 & 10.5 & & & & & & \\
\hline
\end{tabular}

Macroscopic observations of the corroded valve are reported in Figure 11, showing numerous large corrosion products build-ups with colour varying from brown to green.
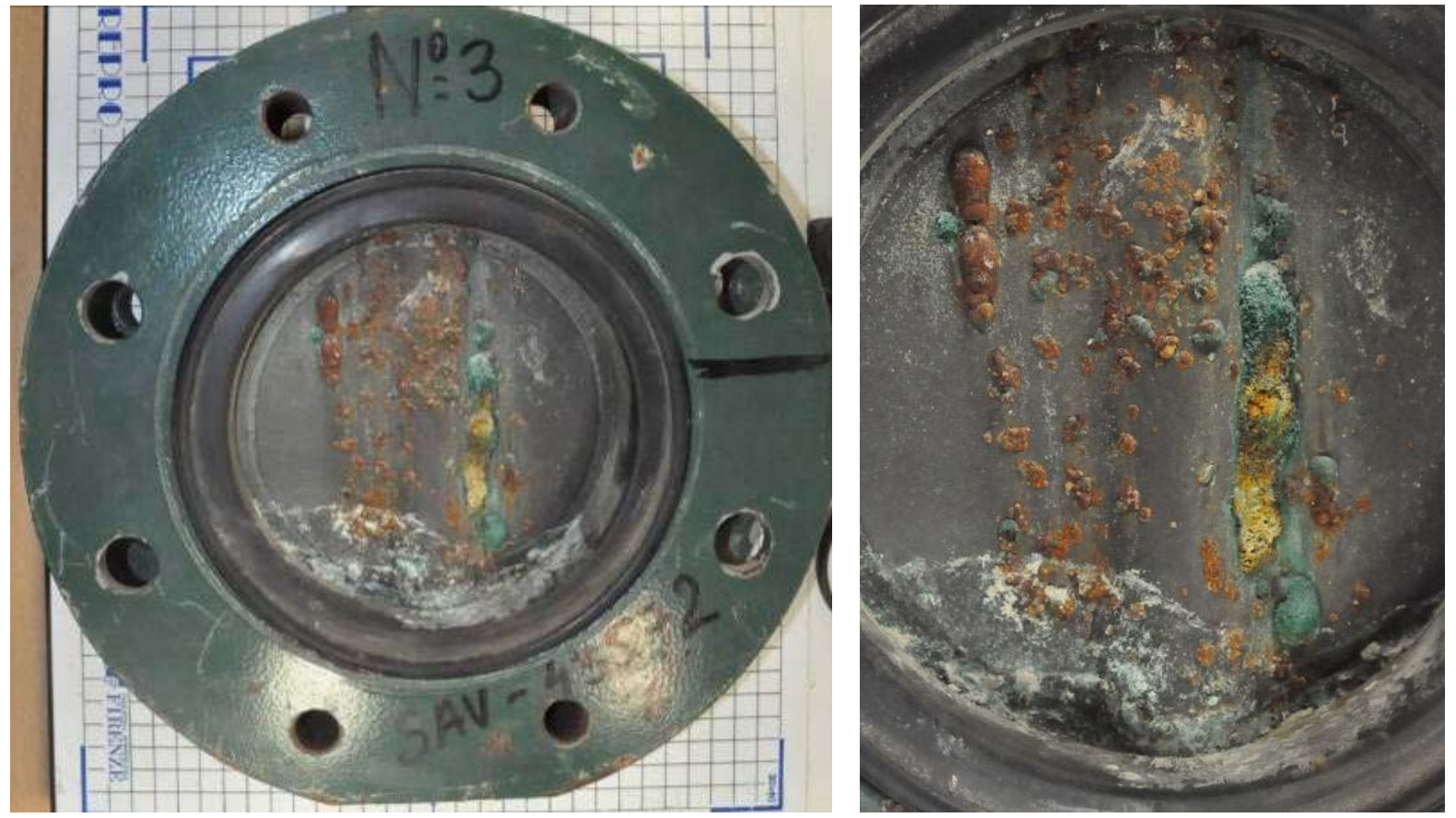

Figure 11: Aspect of the corroded valve

Two cross sections were performed and revealed large and deep attacked areas propagating inside the material with more than $5 \mathrm{~mm}$ penetration.

A complete metallographic analysis was performed and the usual phases of cast NAB were found [33], with no specific defect in the microstructure. Metallographic inspections and scanning electron microscopy (SEM) images clearly showed a selective attack of the material (selective corrosion of the martensitic $\beta$-phase or the eutectoid $\kappa_{\mathrm{III}}$-phase and un-attacked $\alpha$ phase). Semi-quantitative electron discharge X-ray spectroscopy (EDS) analyses have been performed on the corrosion products. The expected copper hydroxychlorides (e.g. $\mathrm{Cu}_{2}(\mathrm{OH})_{3} \mathrm{Cl}$ and $\left.\mathrm{Cu}(\mathrm{OH}) \mathrm{Cl}\right)$, which are usually found on NAB after long exposure period in clean seawater, were identified. However, the presence of sulphur in significant quantities was clearly measured, which may indicate the formation of sulphide compound such as copper sulphide $(\mathrm{CuS})$. Sulfur is usually not expected in material exposed to clean seawater but it has been identified in the literature under the form of copper sulphide on NAB exposed to sulphide-containing seawater [34]. It is very possible that near the disc of the valve, under stagnant conditions, the aeration could be reduced. Hence, a mixture of desaerated water polluted with sulphur and aerated seawater can be formed. This is known very aggressive to most copper alloys, with corrosion rates that can be as high as $10 \mathrm{~mm} / \mathrm{y}$ [8]. In the present 
investigation, the $\mathrm{NAB}$ valve may have been in contact with seawater contaminated with sulphide. A quantity of sulphide as low as $0.01 \mathrm{ppm}$ could induce an increase of the corrosion rate of NAB by a factor of 4 [35]. The origin of sulphide was not determined but it usually comes from the biological activity of sulfate-reducing Bacteria (SRB). The stagnant water is a factor known to help this kind of corrosion by promoting the fouling of the material by microorganisms. The aerobic bacteria consumes the oxygen and then the conditions become anaerobic under deposit which may activate SRB.

To prevent the corrosion of $\mathrm{NAB}$, some recommendations must be strictly followed for applications in seawater:

- Maximum water velocity: $25 \mathrm{~m} / \mathrm{s}$ for NAB,

- Minimum water velocity $0.5 \mathrm{~m} / \mathrm{s}$ in order to avoid stagnant conditions,

- Avoid sulphide or ammonia pollution of the seawater,

- Avoid solid particles (e.g. sand) in the seawater,

- Separate dissimilar metals by installing an insulation spool with necessary length between the two alloys,

- Treat the seawater with a biocide to prevent the development of a biofilm on the surface.

If the pollution by sulphide cannot be avoided, the use of coatings or copper alloys with specific resistance to that parameter is recommended. For instance, Tin bronze (UNS C90700) and leaded gunmetal (UNS C92410) have been proposed by Oldfield et al. for this environment [36].

\section{Cathodic Protection applied to desalination units}

\section{Background}

As shown in the above chapters, the operating conditions of SWRO desalination are demanding and corrosion failures of metallic materials such as stainless steels or copper alloys are frequently experienced when un-adapted grade is used. As mentioned in the introduction, when materials cannot be changed to higher corrosion resistant grades, cathodic protection may be an efficient solution, which is widely used in the offshore industry. Regarding the efficiency of cathodic protection (CP) in desalination units or water handling plant units (e. g. waste water plant), some differences must be considered for the CP design in comparison with "classical" CP design generally used for steel in seawater:

- The material to be protected is stainless steel or copper alloy (passive alloy with different properties compared to the non-passive carbon steel), with large surfaces to be protected (contrary to carbon steel, stainless steels or copper alloys are generally not coated),

- The environmental and operating conditions may be very different from structures exposed in "open" sea (high velocity in seawater handling systems, biofilms on passive alloy surfaces, high pressure in pumps, eventual seawater treatments such as chlorination, etc),

- The resistivity (inverse of conductivity) of the electrolyte cannot be ignored for internal cathodic protection design of the units. For instance, due to the confinement of the electrolyte, the cathodic protection extent will be limited inside pipes. 
It has been admitted that passive alloys such as stainless steel can be cathodically protected at higher potentials than carbon steels, and from this background, the so-called "Resistorcontrolled Cathodic Protection" (RCP) was developed for cathodic protection of stainless steel [37-40]. The basic principle of the method is to apply cathodic protection to a stainless steel pipe using a resistor in series with the anode, in order to restrain the anode current output. It also allows to be far above too low potentials that might be an issue for hydrogen embrittlement of some alloys. The principal of the method is schematically shown in Figure 12 [37].

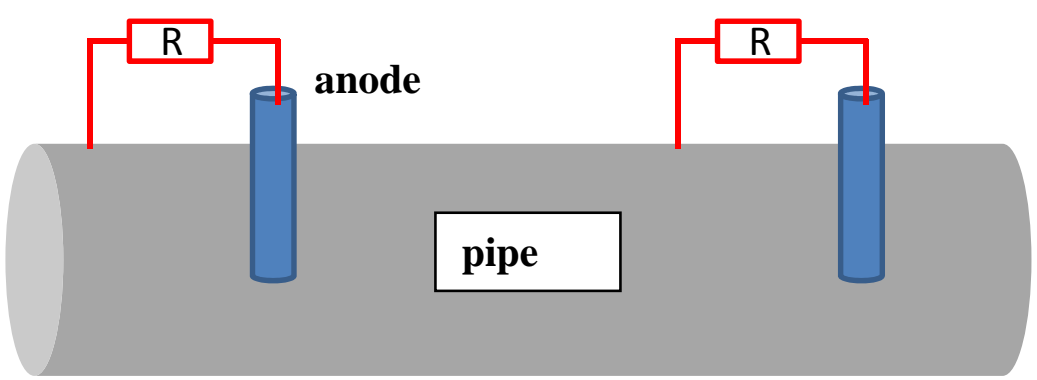

Figure 12: Schematic drawing of the principle of RCP method applied to a pipe system, from ref. [37]

It exist well known "rules of thumb" to determine the cathodic protection extent for internal surface of pipes (i. e. distance of protection inside the pipe from the anode) but the question remains whether or not they are applicable to stainless steels, in the particular application of desalination process. According some existing standards, cathodic protection should be efficient on stainless steel in seawater with potential of about $-600 /-500 \mathrm{mV} / \mathrm{Ag} / \mathrm{AgCl} / \mathrm{Seawater}$ for alloys with PREN below 40 and a potential of about $-300 \mathrm{mV} / \mathrm{Ag} / \mathrm{AgCl} / \mathrm{Seawater}$ for alloys with PREN above 40 (i. e. superduplex and superaustenitic stainless steels) [10,41]. However, these standards are not based on published work and it can be wondered if it concerns all type of geometries (i. e. pitting, severe crevice configurations, etc.) and all types of seawater environments (i. e. effect of temperature, salinity, chlorination, etc.). In reference [11], it is mentioned that sometimes, higher potentials can be considered for protection of stainless steels. According to some authors, higher potentials could be achieved to protect low grade and high grade stainless steels in seawater, namely $-100 \mathrm{mV} / \mathrm{SCE}$ for $316 \mathrm{~L}$ grade, $0 \mathrm{mV} / \mathrm{SCE}$ for duplex 2205-type grade and +100 $\mathrm{mV} / \mathrm{SCE}$ for high grade stainless steels with PREN above 40 (superduplex and superaustenitic stainless steels) $[37,42,43]$. These assumptions are based on the critical crevice potential of stainless steels in seawater which can be found in the literature [37, 44].

However, from another publication [45], crevice corrosion at flanges was observed on high grade passive alloy with a cathodic protection between $-200 /-100 \mathrm{mV} / \mathrm{Ag} / \mathrm{AgCl} / \mathrm{seawater}$, which is far below the criteria of $+100 \mathrm{mV} / \mathrm{SCE}$. This result underlines the complexity of cathodic protection on passive alloys and the need to better understand how protective potential criteria can be better defined. Any critical pitting and/or crevice corrosion potential defined from laboratory studies must be considered with care since the results highly depend on the configuration of the tests (i. e. surface state of coupon, crevice geometry, tested media, etc.). For a same stainless steel composition, the product form (e. g. cast or wrought) of the stainless steel alloy is also of major importance in terms of corrosion resistance properties. This was clearly shown above in the corrosion review of stainless steels in seawater, which means that critical "protective" potential cannot be the same for cast and wrought alloys. 
Also the temperature may have a significant effect on the cathodic protection demand of materials which is due to combinations of the following reasons:

- The dissolved oxygen content decreases with increasing temperatures,

- No biofilm ennoblement is observed above a certain temperature depending on the seawater location (e. g. above about $40^{\circ} \mathrm{C}$ in temperate seawater),

- Above $65^{\circ} \mathrm{C}$, the thermal decomposition of seawater leads to calcareous deposit on metallic surfaces (i. e. decrease of the effective surfaces to be protected),

- In the case of sacrificial anodes, the efficiency of the anodic alloys is temperature dependent.

Few data can be found in the literature about the effect of flow rate on the cathodic protection demand. For cathodic protection of boats, some general recommendations given in Table 6 for the protection of carbon steel can be found, which seems to indicate a very important effect of flow rate on the cathodic protection demand.

Table 6: Recommendation for current density for cathodic protection of carbon steel. Effect of relative flow rate

\begin{tabular}{|c|c|}
\hline $\begin{array}{c}\text { Flow rate } \\
{[\mathbf{m} / \mathbf{s}]}\end{array}$ & $\begin{array}{c}\text { Current density for } \\
\text { cathodic protection } \\
{\left[\mathbf{m A} \mathbf{m}^{2}\right]}\end{array}$ \\
\hline $\mathrm{F}<1$ & 100 \\
\hline $1<\mathrm{F}<3$ & 250 \\
\hline $\mathrm{F}>3$ & 500 \\
\hline
\end{tabular}

However, concerning the effect of flow rate on the current demand for cathodic protection of stainless steel in seawater, some authors found no effect of velocities between 0.1 and $3.2 \mathrm{~m} / \mathrm{s}$ in tests performed in $0.5 \mathrm{ppm}$ - chlorinated seawater [46, 47], which seems in contradiction with the recommendation for carbon steel from Table 6.

Biological activity in the seawater is of extreme importance regarding corrosion processes of stainless steels for both initiation and propagation [38, 48-55]. It results in the so-called potential ennoblement for passive materials (i. e. potentials from about $-150 \mathrm{mV} / \mathrm{SCE}$ before biofilm settlement and about $+300 \mathrm{mV} / \mathrm{SCE}$ after biofilm settlement), increasing the risk of localized corrosion initiation. Besides the ennoblement of the open-circuit potential, the biofilm results in an effective catalyze of the oxygen reduction on stainless steel exposed to natural seawater [56]. This will result in a significant increase of the efficiency of the oxygen reduction at biofilmed surfaces compared to sterile conditions. For this reason, biofouling is probably the most important parameter to consider when designing cathodic protection of stainless steel in seawater: the cathodic current demand will be significantly higher in biofilmed conditions compared to not biofilmed conditions. This means that the current demand to polarize stainless steels below protective potential will be much higher in presence of biofilm than in not biofilmed conditions.

Biocide treatments such as chlorination are often used for seawater applications to prevent the formation of biofouling (e. g. seawater heat exchangers or piping systems). It is generally admitted that a residual chlorine content between 0.1 and $0.2 \mathrm{ppm}$ can prevent the formation of the biofilm and reduce the corrosion propagation compared to not chlorinated seawater [48, 57]. However, residual chlorine content above $0.5 \mathrm{ppm}$ may significantly increase the risk of localized corrosion initiation on stainless steels [48]. In natural seawater, the cathodic 
protection has been reported to be the most efficient when used in combination with chlorination [48]. From the literature, in chlorinated media, "low" current densities are required to polarize stainless steel surfaces to expected safe potential values [45-48]. The main conclusion about the effect of chlorination on cathodic protection of stainless steel is the significant decrease in the cathodic current demand to polarize stainless steel compared to unchlorinated biofilmed situation. In the case of cathodic protection with sacrificial anodes, it means that lower anode consumption should be observed in chlorinated conditions and that internal cathodic protection should be efficient on longer distances from the anode.

From this background, an R\&D project was initiated to better understand the internal cathodic protection of stainless steel in the specific operating conditions of seawater reverse osmosis desalination units.

\section{Experimental}

Some devices of SWRO desalination units were installed on a laboratory seawater loop in our marine corrosion station. The following devices are used for laboratory testing:

- A vertically mounted centrifugal made of 316L grade stainless steel (UNS S31603), working at pressures from atmospheric to $10 \mathrm{bar}$,

- A butterfly valve made of 316L grade stainless steel (UNS S31603),

- Superduplex UNS S32750 pipe (1" diameter).

The pump was mounted as shown in Figure 13 with the possibility to implement a monitored cathodic protection system. The pump is driven with electronic control system, allowing pressure and flow velocity control. Both a cathodic protection system with sacrificial anode and with impressed current using rectifier can be implemented with the proposed set-up. Data loggers adapted for electrochemical measurements allowed to measure and record the potential of the metallic surfaces and the galvanic currents. All the plastic piping system was made of pressure resistant Corzan CPVC. 

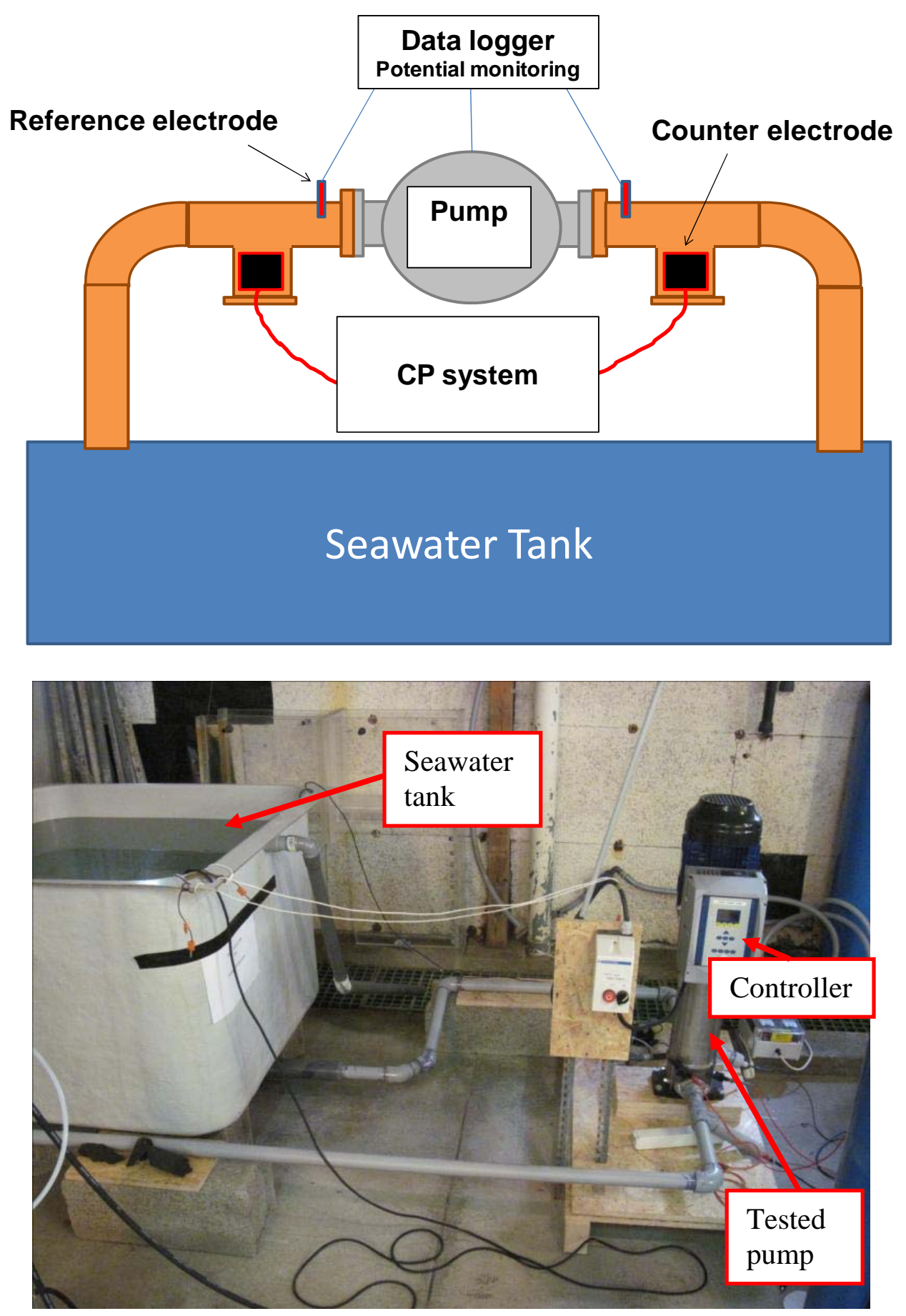

Figure 13: Schematic drawing and photograph of the monitored 316L stainless steel pump

In a separated seawater loop, a 2 m-long pipe was monitored by introducing 9 reference electrodes (through specifically designed access fittings) along the pipe (i. e. at different distance from the anode). A circulation pump allowed to control the water flow rate inside the tube. A schematic drawing and a photograph of the set-up is given in Figure 14. Here again, both a cathodic protection system with sacrificial anode and with impressed current could be implemented. 

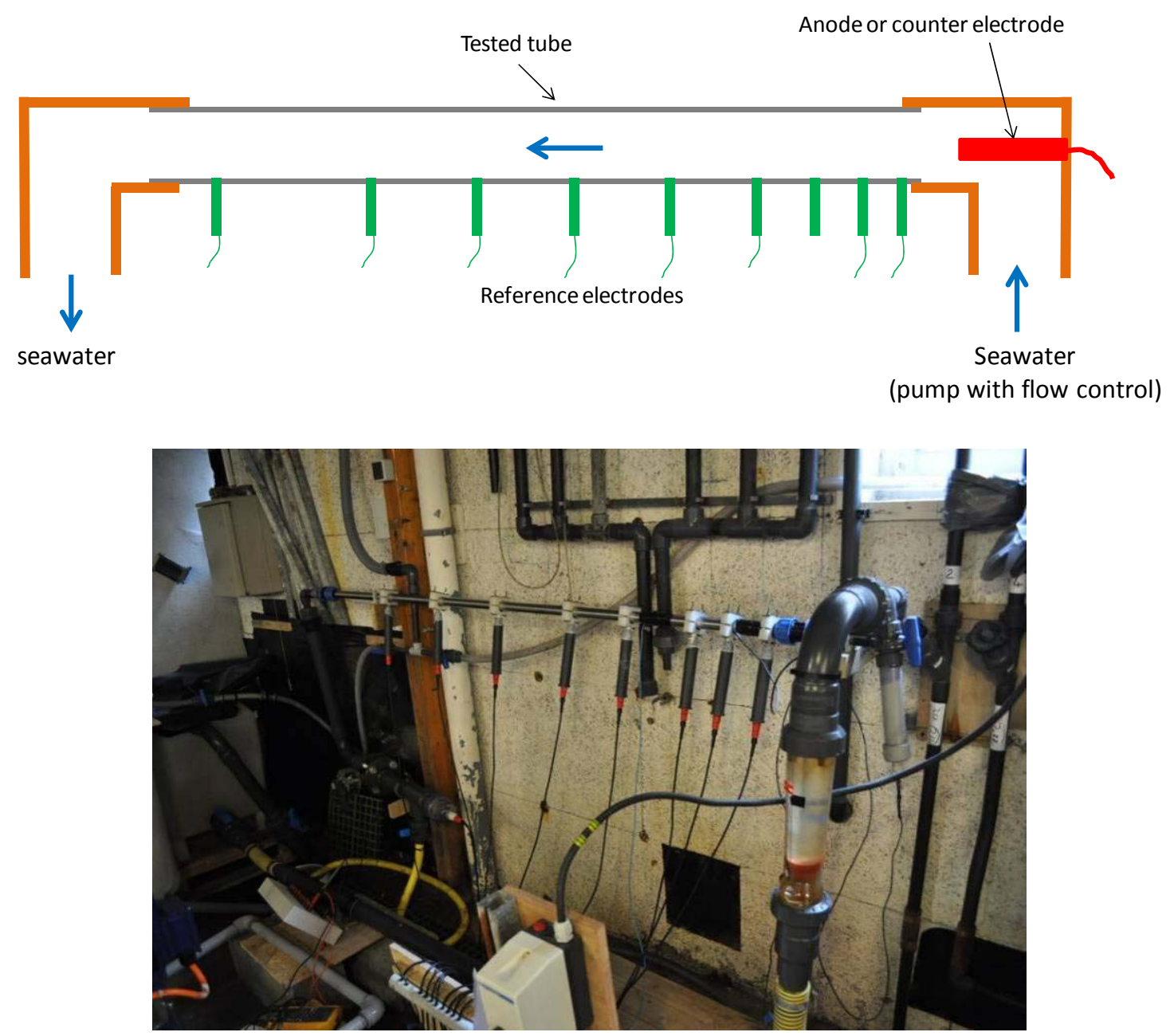

Figure 14: Schematic drawing and photograph of the $2 \mathrm{~m}$-long monitored superduplex stainless steel pipe

A stainless steel butterfly valve made of UNS S31603 (316L) was also tested. The butterfly valve was mounted in a similar seawater loop as the one described for tube testing, allowing flow rate control and implementation of cathodic protection and monitoring (potential and current) systems. Photograph of the valve before exposure is given in Figure 15. 


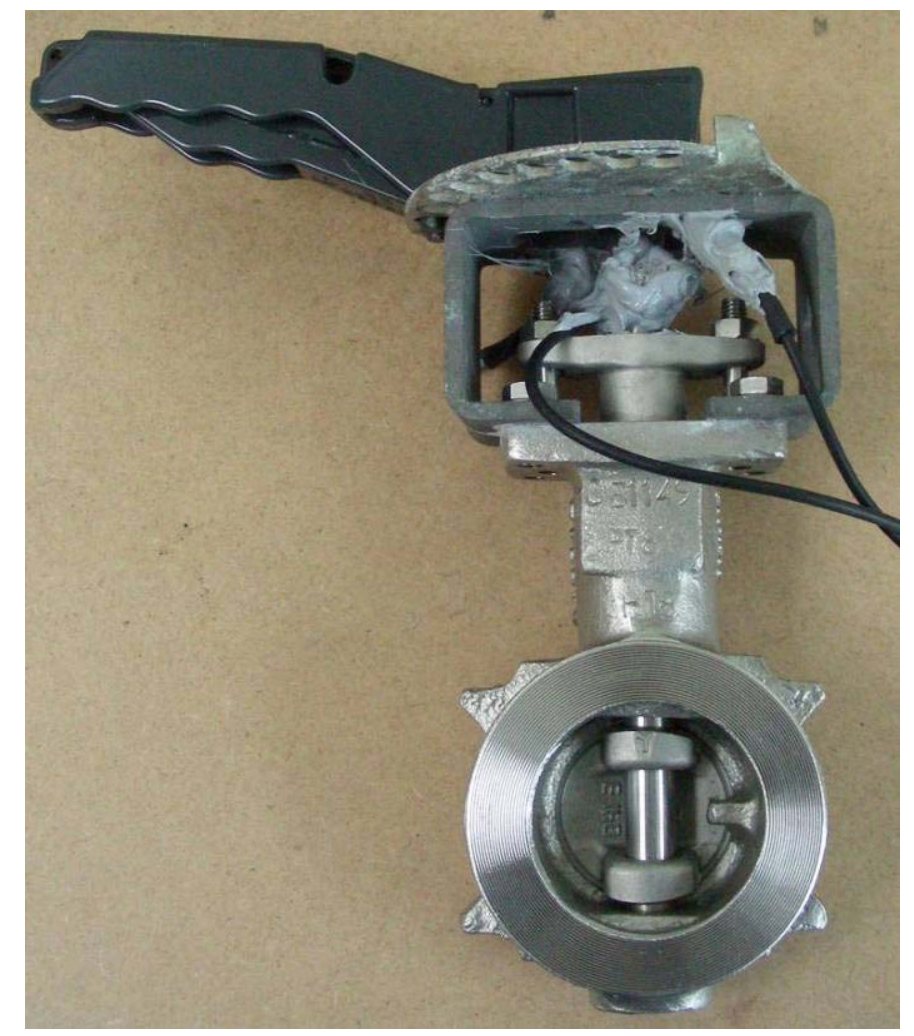

Figure 15: Photograph of the 316L butterfly valve before exposure

A commercial software called PROCOR ${ }^{\mathrm{TM}}$ was used for the modeling of the cathodic protection. This software, initially developed to design cathodic protection systems for immersed or buried structures is an appropriate numerical modeling based on a Boundary Element Method which computes electrochemical potentials and current densities on the structure and everywhere inside the electrolyte [58, 59]. Using direct derivation of the electrical potential, the software calculates the Underwater Electric Potential field (UEP), the DC electric field related to corrosion within the electrolyte. The software solves the Laplace equation $\Delta \mathrm{u}=0$, checked by the electrical potential, obtained after combining the Ohm law $(j=-\sigma \nabla u)$ and the current conservation equation $(\operatorname{div}(j)=0)$.

The results and accuracy of the cathodic protection modelling depends on:

- geometric meshing

- the electrolyte conductivity

- the anode electrochemical behavior (impressed current, impressed potential or anodic polarization curve)

- the cathodic electrochemical behaviors (cathodic polarization curve).

The output data given by the software are:

- potential distribution on the structure

- current densities provided by cathodic protection

\section{$\underline{\text { Results and discussions }}$}

Polarization curves were directly performed on the pump in natural seawater for not biofilmed surfaces and biofilmed surfaces. To draw polarization curve with no biofilm, the measurements were performed in the first 2 days of exposure, before biofilm establishement 
on surfaces. The polarization curves with biofilmed surfaces were performed after at least 2 weeks of exposure, to ensure biofilm establishment on the surfaces. For each point of the polarization curves, the stabilization of both potential and current was waited before implementing the measured values in the graph. The results are given in Figure 16. As expected, a significant difference was found between not biofilmed and biofilmed conditions, confirming that under biofilm condition, the current demand to protect surfaces with cathodic protection system is very high. This may appear as serious issue concerning internal cathodic protection because higher protection current will be required (i. e. lower anode lifetime in case of protection with sacrificial anode) to protect smaller lengths from the sacrificial anodes (i. e. more anodes to be correctly distributed along the structures).



Figure 16: Polarization curves of the centrifugal pump in natural seawater with and without biofilmed surfaces.

To investigate the effect of pressure in the pump on the cathodic protection, measurements were performed at impressed potentials of $-300 \mathrm{mV} / \mathrm{SCE}$ and $-600 \mathrm{mV} / \mathrm{SCE}$, from 1 bar to 6 bars. Results are summarized in Table 7 and for the tested configuration (biofilmed conditions), no significant influence of the pressure was noticed on the cathodic current demand.

Table 7: Required current densities in $\mathrm{mA} / \mathrm{m}^{2}$ as a function of the pressure in the $316 \mathrm{~L}$ centrifugal pump

\begin{tabular}{|c|c|c|}
\hline & $\begin{array}{c}\text { Impressed } \\
\text { potential } \\
\mathbf{- 3 0 0 ~} \mathbf{~} \text { V/SCE }\end{array}$ & $\begin{array}{c}\text { Impressed } \\
\text { potential } \\
\mathbf{- 6 0 0} \mathbf{~ m V / S C E}\end{array}$ \\
\hline $\mathbf{1}$ bar & 187 & 288 \\
\hline $\mathbf{3}$ bar & 189 & 289 \\
\hline 6 bar & 191 & 292 \\
\hline
\end{tabular}


For all the testing conditions, the plastic piping and fittings made of Corzan CPVC was perfectly resistant.

With the monitored pipe described in the experimental part, the potential gradient along the pipe was measured in natural seawater at $25^{\circ} \mathrm{C}$ as a function of the distance from the anode and as a function of exposure time. The results are given in Figure 17, showing that potentials stabilized after about 1 week of exposure in natural seawater. It corresponds to the establishment of biofilm on surface which significantly increases the cathodic current demand for polarization.

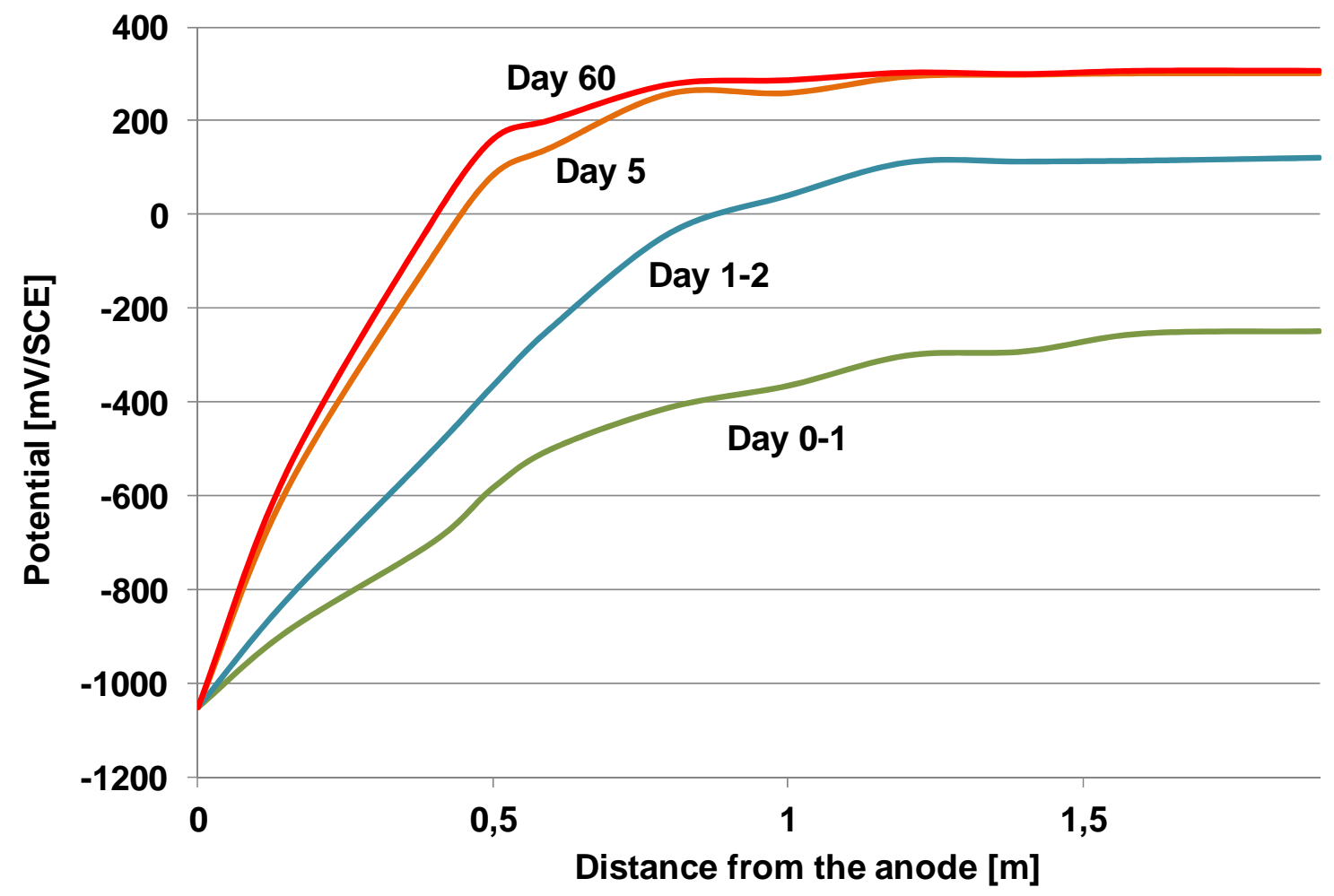

Figure 17: Internal potential distribution along the superduplex stainless steel pipe (1" diameter) as a function of the distance from the anode in natural seawater at $25^{\circ} \mathrm{C}$

The settlement of biofilm was clearly confirmed with the potential versus time monitoring of a superduplex stainless steel freely exposed in natural seawater (i. e. no cathodic protection). The results are given in Figure 18 and the evolution of the potential (i. e. potential ennoblement due to biofouling) clearly corresponds to the evolution of the potential gradient along the pipe. Taking into consideration the criteria of $-300 \mathrm{mV} / \mathrm{SCE}$ as a safe potential, the protected distance is decreased by a factor of about 5 when biofilm developed on surfaces. It must be mentioned that this value is only valid for the tube geometry that was used in the test (other geometries will be tested later in the project). 


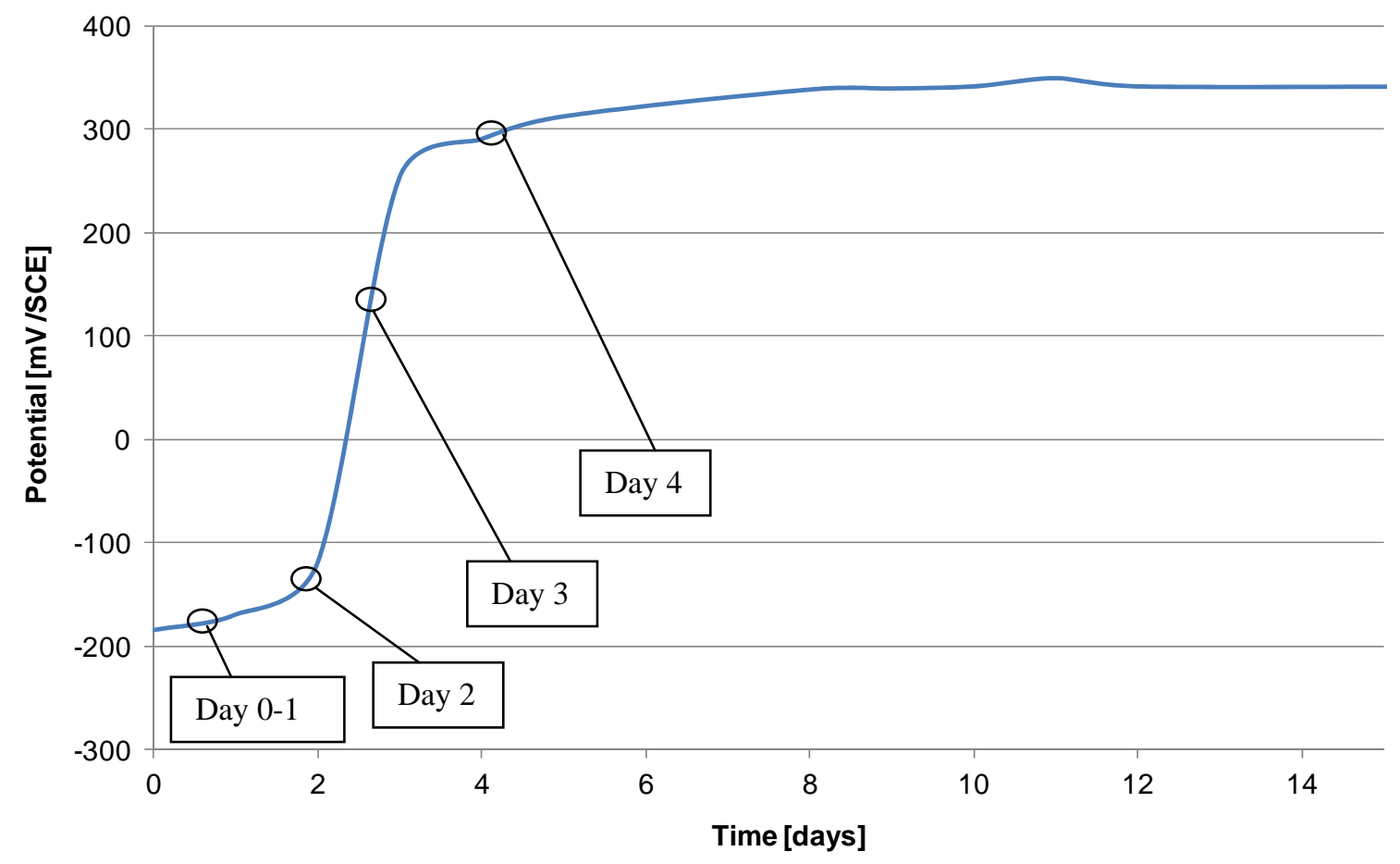

Figure 18: Open-circuit potential of superduplex stainless steel with no cathodic protection in natural seawater at $25^{\circ} \mathrm{C}$ (to be associated with results from Figure 17)

An innovating method was proposed to allow the drawing of pseudo-polarization curves using a single pipe. The reference electrodes are well distributed along the pipe and it was possible to measure both the potential of the pipe at the location of reference electrodes and the potential difference between 2 consecutive reference electrodes, as schematically shown in Figure 19.

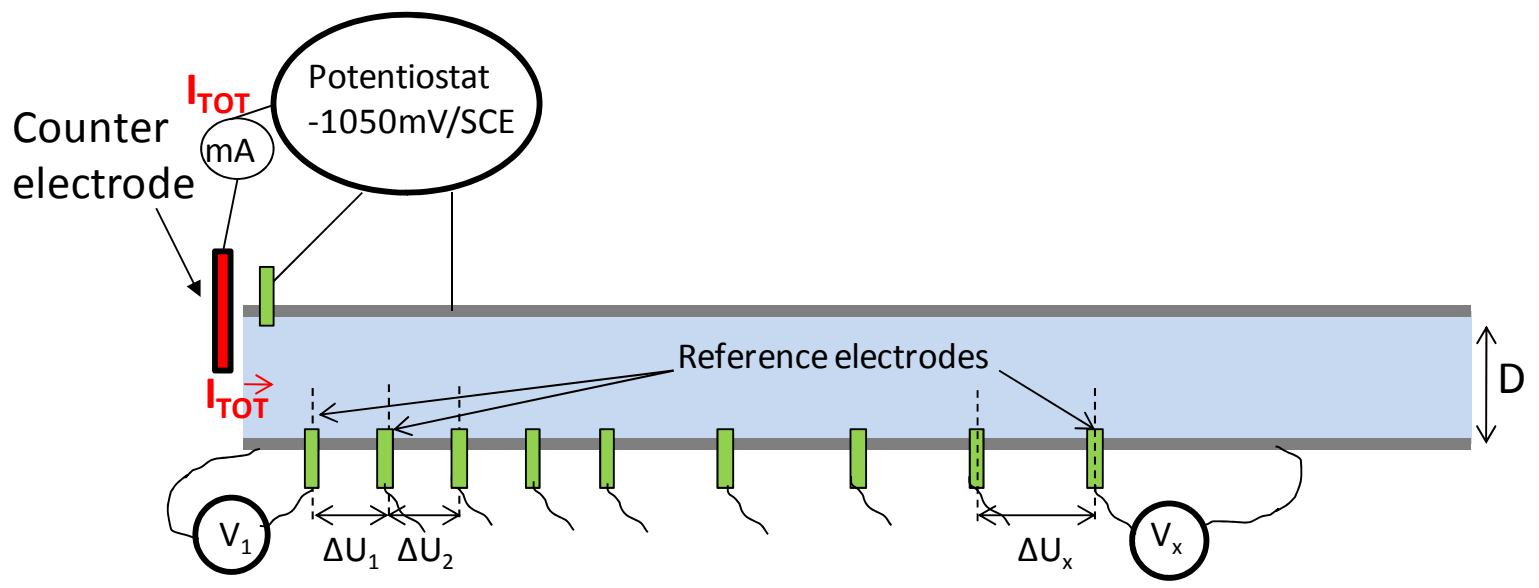

Figure 19: Monitored pipe for pseudo-polarisation curves drawing

Then for each distance from the anode, it is possible to associate a potential $\left(\mathrm{V}_{\mathrm{x}}\right)$ and a current density consumption $\left(i_{\mathrm{x}}\right)$ as a result a single monitored pipe can be used to draw long-term pseudo polarization curves. This method appeared useful because to draw "usual" pseudopolarization curves for $\mathrm{CP}$ design, one point of the curves is generally obtained with long term exposure of one specimen $[60,61]$, and only few points are generally used to draw one composite curve from several specimens. This type of measurement was used to draw pseudo 
polarization curves, before and after biofilm development on stainless steel tube. These pseudo-polarization curves were then implemented in PROCOR ${ }^{\mathrm{TM}}$ software for modeling. The results are given in Figure 20 and Figure 21, for the flow rate of $0.2 \mathrm{~m} / \mathrm{s}$. In Figure 21, both the modeled and the measured potential gradient are shown and a very good fitting was found for the tested configuration, with and without biofilm.
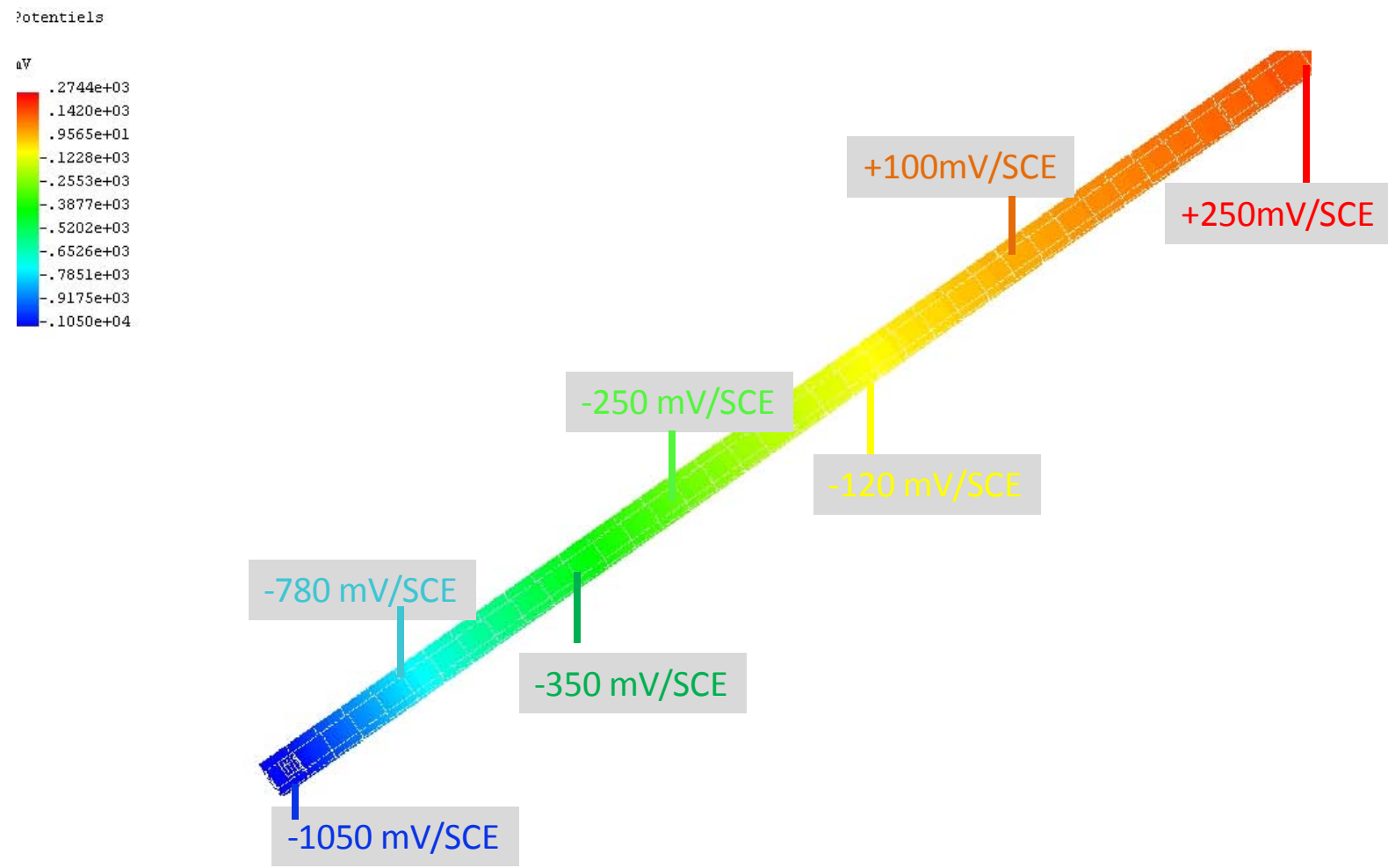

Figure 20: PROCOR ${ }^{T M}$ modeling result for the used pipe in presence of biofilm 


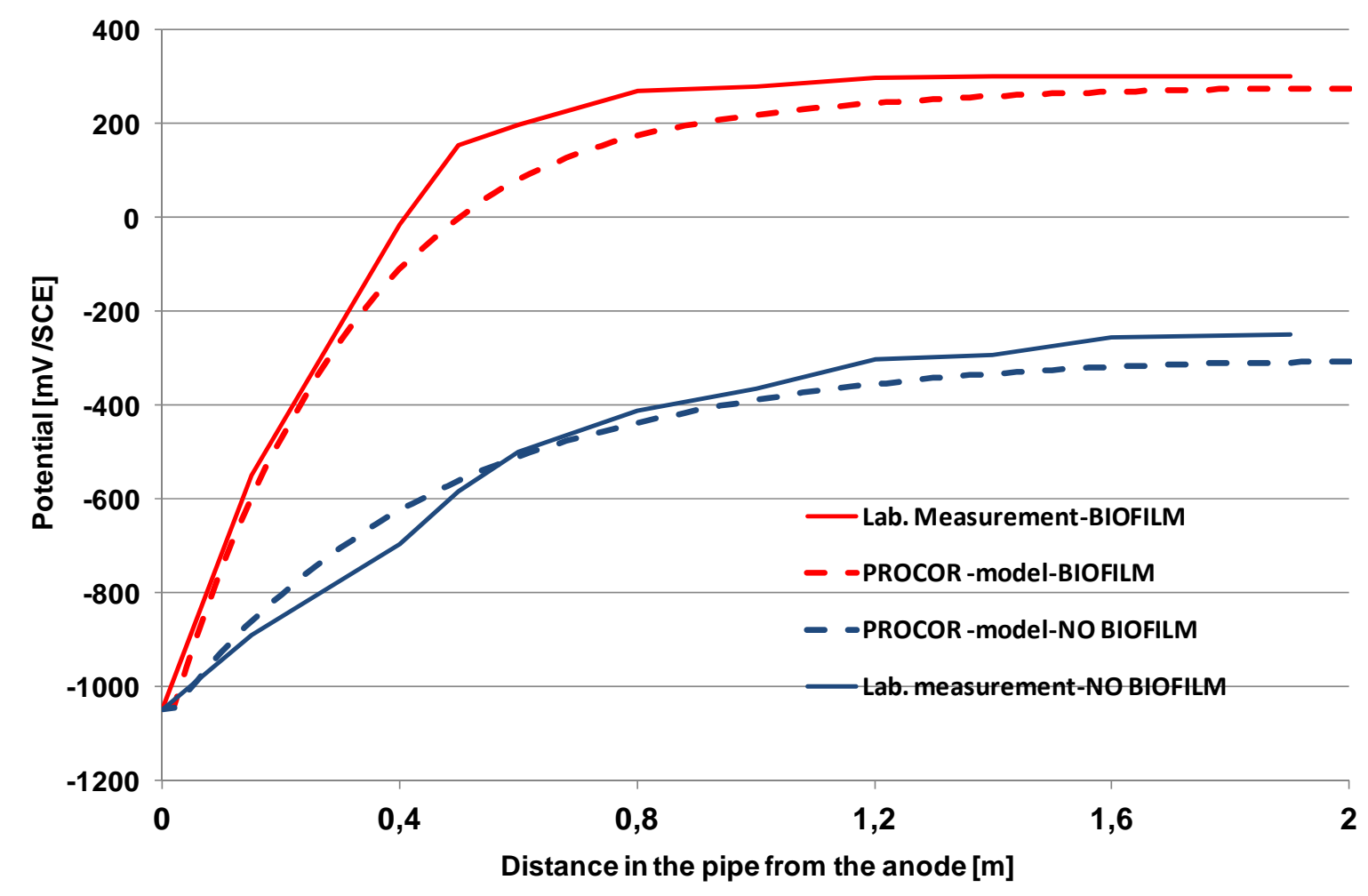

Figure 21: Potential gradient along a pipe with zinc anode, comparison between measured laboratory results and modeling with PROCOR ${ }^{T M}$

The effect of flow rate (i. e. velocity) was also investigated, drawing pseudo-polarisation curves for the following tested conditions:

- Stagnant (flow rate $=0 \mathrm{~m} / \mathrm{s}$ )

- Low flow rate (flow rate $\sim 0.2 \mathrm{~m} / \mathrm{s}$ )

- High flow rate (flow rate $\sim 4.0 \mathrm{~m} / \mathrm{s}$ )

The modeled results were also in good line with the measured laboratory values: the effect of flow rate in natural seawater (biofilmed conditions) revealed a noticeable difference between flowing and stagnant conditions (in the tested configuration, the protected length was about $15 \%$ longer in stagnant conditions compared to flowing conditions). However, no significant differences were found between the "low" and the "high" flow rate, indicating that under biofilmed conditions, a "slow" flow rate is already critical for the kinetics of cathodic reduction reactions.

For the tested stainless steel butterfly valve, very similar "cathodic protection" results as that measured for the pipe and the pump were found (i. e. similar polarization curves with similar effect of biofouling and flow rate).

In parallel, field measurements are performed in an existing SWRO desalination plant in Israel. The results from field testing are coming from monitored cathodic protection system (RCP system) that was already installed in the plant [43, 47]. Both high pressure pumps and pipes are equipped with cathodic protection with adapted monitoring systems allowing electrochemical potential and current measurements. In the next step of the study, these data will be analyzed and compared with laboratory work. The modeling work performed from 
laboratory results will be confronted to field measurements and used to understand and optimize the full scale cathodic protection systems.

\section{Conclusions and futur works}

The present document gives a brief review of corrosion resistance of stainless steels and copper-alloy in seawater desalination units operating at ambient temperature (e. g. reverse osmosis process). It shows that a good understanding and control of operating conditions and a careful material selection must be performed to avoid corrosion failures. For existing corrosion, cathodic protection, generally used for protection of carbon steel, may be applied on stainless steel or copper alloy. However, in the particular service conditions of seawater reverse osmosis desalisation plants, the actual efficiency of "usual" cathodic protection may be strongly affected, as a result a carefull and specific cathodic protection design should be considered. The data enabling a CP design adapted to specific units of a SWRO desalination plant is the subject of a current study, using both specific laboratory tests and field measurements in a full scale desalination plant. The main first conclusions from this on-going investigation are listed below:

- The effect of biofouling on the cathodic protection current demand was clearly put in evidence and quantified for

- Internal protection of stainless steel tube,

- Protection of stainless steel butterfly valves,

- Protection of stainless steel pump.

- An innovating method was developed and used to draw pseudo-polarization curves of stainless steel using a single pipe, and the results from this method are very satisfying regarding the accuracy of the modeling with $\mathrm{PROCOR}^{\mathrm{TM}}$.

- The current demand for cathodic protection of all the tested stainless steel devices is higher in flowing condition than in stagnant conditions.

- In flowing conditions, the flow rates from 0.2 to $4.0 \mathrm{~m} / \mathrm{s}$ did not revealed significant differences in terms of current demand for cathodic protection of stainless steel surfaces in natural seawater.

- For the tested pump, the effect of pressure was not significant in terms of current demand for cathodic protection of stainless steel surfaces in natural seawater.

The next steps of this study are summarized below:

- Laboratory investigation in chlorinated seawater,

- Further investigation of the field results. Comparison with laboratory results and modeling of field facilities,

- Measurements on bronze aluminium valve,

- Further investigation on the criteria and the method to protect stainless steel considering the tested environments.

\section{Acknowledgements}

RISE (Sweden) and Veolia Water (France) are gratefully acknowledged for financial support. Ifremer is thanked for precious technical support in this study. Gulnara Omarbekova from Lubriziol Advance Material is also gratefully acknowledged for the supply and advices of all pressure bearing plastic elements used in the laboratory set-up. Jean-Michel Hamoignon and Charles Leballeur are acknowledged for their help in the experimental set-ups. 


\section{References}

1. Abu-Safiah A., Material Selection for the High Pressure Section of Seawater RO Plants. Desalination, 84, pp 279-308, 1991.

2. Larché N., Thierry D., Debout V., Blanc J., Cassagne T., Peultier J., Johansson E., and Taravel-Condat C., Crevice corrosion of duplex stainless steels in natural and chlorinated seawater. Duplex World 2010, Beaune, France, October 11-13, 2010.

3. Larché N. and Thierry D., Corrosion performance of $25 \% \mathrm{Cr}$ superduplex stainless steel for different seawater applications. Stainless Steel World, Maastricht, The Netherlands, 2011.

4. Yakuwa H., Miyasaka M., and Sugiyama K., Evaluation of Crevice Corrosion Resistance of Duplex and Super Duplex Stainless Steels for Seawater Pumps. Corrosion, NACE Paper Nº 09194, 2009.

5. $\quad$ Strandmyr O. and Hagerup O., Field Experience with Stainless Steel Materials in Seawater Systems. Corrosion'98, Houston, NACE, paper N. 707, 1998.

6. Havn T., Material Engineering and Fabrication Experiences. paper 56, NACE CORROSION'95, 1995.

7. Johnsen R., North Sea Experience with the Use of Stainless Steel in Seawater Applications. EFC Publication 10, The Institute of Materials, 1993.

8. Francis R., The Corrosion of Copper and its Alloys: A practical Guide for Engineers, NACE International, NACE PRESS, 2010.

9. Recommended Practice DNV-RP-B401 - Cathodic Protection Design, 2005.

10. ISO 15589-2:2004, 2004.

11. General Principle of Cathodic Proptection in Seawater. Standard NF EN 12473, 2000.

12. http://www.protectioncathodique.net.

13. Herbsleb, G., Der Einflu $\beta$ von Schwefeldioxid, Schwefelwasserstoff und Kohlenmonoxid auf die Lochkorrosion von austenitischen Chrom-Nickel-Stählen mit bis zu 4 Massen-\% Molybdän in 1 M Natriumchlorid-Lösung. Materials and Corrosion, V. 33, $\mathrm{N}^{\circ} .6$, p. 334-340, 1982.

14. Combrade P., Crevice Corrosion of Metallic Materials. Corrosion Mechanisms in Theory and Practice, $2^{\text {nd }}$ edition p. 358, 2002.

15. ASTM G48-03, Standard Test Method for Pitting and Corrosion Resistance of Stainless Steels and Related Alloys by Use of Ferric Chloride Solutions. American Society for Testing and Materials, 2003.

16. Espelid B., Development of a New Crevice Corrosion Qualification Test for Stainless Steels. Stainless Steel World, 2003.

17. Kivisakk U., Crevice Corrosion Testing of Stainless Steel Tubes. Corrosion'04, 2004.

18. Larché N. and Thierry D., Crevice Corrosion of Stainless Steels for Seawater Applications. Join Industry Project, Institut de la Corrosion, IC-79030, 2009.

19. Aylor D. M., Hays R. A., Kain R. M., and Ferrara R.J, Crevice Corrosion Performance of Candidate Naval Ship Seawater Valve Materials in Quiescent and Flowing Natural Seawater. NACE Corrosion paper N.329, 1999.

20. Material Selection Table for Seawater Service. Internal Communication of Arcelor Mittal.

21. Larché N., Field inspection of the corrosion in the SWRO desalination plant in the mediteranean sea. Comission report IC 89670-1, Institut de la Corrosion, Véolia consultancy, 2009.

22. Roscoe C. V. and Gradwell K. J., The History and Development of Duplex Stainless Steels. Duplex Stainless Steel'86, Paper Nº.34, 1986. 
23. Desestret A. and Catelin D., Special Stainless Steels for Use in Seawater. Seminar on the economic and technological aspects of the protection of steel against corrosion, Genova 7-11 May, 1984.

24. Havn T., Material Selection and Engineering Evaluations, Seawater Systems. Aker Maritime, Norway, 2000.

25. Drugli J. M., Rogne T., Johnsen R., and Olsen S., Corrosion Testing of Stainless Steel Weldments in Seawater, $\mathrm{NaCl}$, and $\mathrm{FeCl}_{3}$ Solutions. NACE Corrosion paper N ${ }^{\circ} .410$, 1988.

26. Steinsmo U., Valen S., Gartland P. O., and Bardal E., Effect of Temperature on Propagation of Crevice Corrosion of High-Alloyed Stainless Steels in Natural Seawater. 10 ${ }^{\text {th }}$ Europ. Corr. Cong. Paper N.244, 1993.

27. Skjellevick H. and Salbu H., Ni-based Alloys and Weld Overlays for Seawater Systems. Sea Water Corrosion of Stainless Steels - Mechanisms and Experiences, SINTEF, paper $\mathrm{N}^{\circ} .17,1995$.

28. Manfredi C., Simison S., and De Sanchez S. R., Selection of Copper Base Alloys for Use in Polluted Seawater. Corrosion Nace, V. 33, N. 8, 1987.

29. Sneddon A. D. and Kirkwood D., The Influence of Fouling Upon Corrosion Rates of Steels and Copper-Nickel Alloys in Sea Water. UK. Corrosion 88, Brighton pp. 81-96, 1988.

30. Larché N., Blanc J., Iken H., and T. D., Galvanic corrosion induced by the use of high alloy stainless steel in seawater applications. NACE Corrosion, Saltlake City, Utah, 2012.

31. Francis R., Galvanic Corrosion: A Practical Guide for Engineers, 2001.

32. Circuits Eau de Mer, Traitements et Matériaux, édition Technip, 1993.

33. Warthon J., Barik R. C., Kear G., Wood R. J. K., Stokes K. R., and Walsh F. C., The Corrosion of Nickel-Aluminium Bronze in Seawater. Corrosion Science 47, pp. 33363367, 2005.

34. Schüssler A. and Exner H. E., The Corrosion of Nickel-Aluminium Bronzes in Seawater-II, The Corrosion Mechanism in Presence of Sulfide Pollution. Corrosion Science 34, pp. 1803-1815, 1993.

35. Hack H. P., Galvanic Corrosion of Piping and Fitting Alloys in Sulfide-Modified Seawater. ASTM STP978, pp. 339-351, 1988.

36. Oldfield J. W. and Masters G. L., Collation of Data Comparing Properties of Aluminium Bronze with Cast Stainless Steels and Ni-Resist in Offshore Seawater Environments. 1996.

37. Johnsen R., Gartland P. O., Valen S., and Drugli J. M., Internal Cathodic Protection of Seawater Piping System by the Use of RCP Method. NACE Corrosion, Paper 559, 1996.

38. Rogne T. and Steinsmo U., Practical Consequences of the Biofilm in Natural Sea Water and of Chlorination on the Corrosion Behaviour of Stainless Steels. Sea Water Corrosion of Stainless Steels - Mechanisms and Experiences, EFC Publication 19, 1996.

39. Gartland P. O. and Drugli J. M., Methods for Evaluation and Prevention of LOcal and Galvanic Corrosion in Chlorinated Seawater Pipelines. NACE Corrosion, paper 408, 1992.

40. Gartland P. O., Johnsen R., Valen S., Rogne T., and Drugli J. M., How to Prevent Galvanic Corrosion in Seawater Piping Systems. NACE Corrosion, Paper 496, 1996.

41. Principe Géréraux de la Protection Cathodique en Eau de Mer. Standard NF EN 12473, 2000. 
42. Magne Wigen S., Osvoll H., and Gartland P. O., Efficient Cathodic Protection of Stainless Steel Small Bore Tubing. NACE Corrosion, paper 07078, 2007.

43. Magne Wigen S., Corrosion Problems and Corrosion Mitigation Experiences on 6Mo Stainless Steel Seawater Systems on the Sleiner Plateforms-North Sea. NACE Corrosion, paper 08263, 2008.

44. Rogne T. and Drugli J. M., Criteria for Selection of Stainless Steels. Publication at NACE conference, Sandefford, Norway, 1993.

45. Grolleau A. M., Le Guyader H., Debout V., Dolignon N., Pautasso J. P., and Blanc J., Internal Cathodic Protection of Seawater Piping Systems - Evaluation by Use of Computer Modelling and Comparisons to Experimental Results. Eurocorr 08, Edinburgh, UK, 7-11 September, 2008.

46. Drugli J. M. and Rogne T., Cathodic Properties of Stainless Steel in Chlorinated Seawater. SINTEF Report STF F95378, 1995.

47. Drugli J. M., Rogne T., Gartland P. O., and Johnsen R., Cathodic Protection of Stainless Steels in Chlorinated Sea Water and Other Saline Water Solutions - A new Approach by Use of the RCP Method. EFC Publication 19, 1996.

48. Mollica A. and Scotto V., Mechanism and Prevention of Biofilm Effect on Stainless Steel Corrosion. Sea Water Corrosion of Stainless Steels - Mechanisms and Experiences, EFC Publication 19, 1996.

49. Audouard J. P., Thierry D., Féron D., Compère C., Scotto V., Wallen B., Stigenberg A. H., and Rogne T., Crevice Corrosion Resistance of Stainless Steels in Natural Sea Water. Results of a Paneuropean Test Programme. Stainless Steels 96, 3-5 Juin 1996, Düsseldorf, Germany, p83-88, 1996.

50. Holthe R., Bardal E., and Gartland P. O., Time Dependence of Cathodic Properties of Materials in Seawater. MP 28-6, 1989.

51. Johnsen R. and Bardal E., Cathodic Properties of Different Stainless Steels in Natural Seawater. Corrosion 41, pp. 296-302, 1985.

52. Zhang H. J. and Dexter S. C., Effect of Biofilms on Crevice Corrosion of Stainless Steels in Coastal Seawater. Corrosion Science, pp. 56-66, 1995.

53. Féron D., Comportement des Aciers en Environement Naturel: cas des Aciers Inoxydables en Eau de Mer Naturelle. Matériaux et Techniques, Vol. 93, pp. 43-58, 2005.

54. Scotto V., Beggiato M., Marcenaro G., and Dellepiane R., Microbial and Biochemical Factors Affecting the Corrosion Behaviour of Stainless Steels in Seawater. EFC Publication $\mathrm{N}^{\circ}$. 19, 1996.

55. Le Bozec N., L'Her M., Compère C., Laouenan A., Costa D., and Marcus P., Influence of Stainless Steel Surface Treatment on the Oxygen Reduction Reaction in Seawater. Corrosion Science 43, pp. 765-786, 2001.

56. Mollica A. and Traverso E., Proc. of Int. Conf. on Corrosion in Natural and Industrial Environments: Problems and Solutions, Grado, NACE Inter. Italia section, p. 249.

57. Ventura G., Traverso E., and Mollica A., Effect of NaClO Biocide Additions in Natural Sea Water on Stainless Steel Corrosion Resistance. Corrosion Vol. 45, N. 4, 1989.

58. Chauchot P., Bigourdan B., and Lemoine L., Cathodic Protection Systems Modelled by the PROCOR Software. NACE Corrosion'89, paper 401, New Orleans, USA, 1989.

59. Bigourdan B., Le Flour D., Chauchot P., and Compère C, Modelling of Cathodic Protection Systems: Advantages and Limitations. Eurocorr 04, Nice, France, 2004.

60. Wang W., Hartt W. H., and Chen S., Sacrificial Anode Cathodic Polarization of Steel in Seawater. Corrosion Science V. 52, N. 6, pp. 145, 1996. 
61. Festy D., Le Flour D., Vittonato J., Merchant I, and Morten Hesjevik S., ICP-DATA: In Situ Data Collection for Cathodic Protection Design. NACE Corrosion, Conference Paper 11050, 2011. 